\title{
KONVERGÁL-E A SZÜLETÉSKOR VÁRHATÓ ÉLETTARTAM EURÓPÁBAN?
}

\section{Kovács Katalin}

\section{ÖSSZEFOGLALÓ}

A tanulmány a születéskor várható élettartamok alakulására vonatkozó elméleti megközelítések közül az úgynevezett klub-elméleteket ismerteti részletesen. Empirikus vizsgálódásában az WHO Európai régiójában élő férfiak és nők születéskor várható élettartamának 1971 és a 2010-es eleje közötti alakulását elemzi. A várható élettartam fejlődését olyan országokban is tekintetbe veszi, ahol csak rövidebb időszakra nézve álltak adatok rendelkezésre. A várható élettartamok alakulása szerint az országokat trend-elemzés segítségével csoportosítja.

A női várható élettartamokat illetően az országok három csoportba voltak sorolhatóak. A nyugat-európai, a kelet-európai és a kelet-közép-európai országcsoportokban a születéskor várható élettartamok azonban nem különböztek egymástól olyan mértékben, hogy az országcsoportokat elkülönült kluboknak tekinthessük. A férfiak esetében azonban az idők folyamán legalább négy országcsoport (nyugat-európai, kelet-európai, balti és közép-kelet-európai) különült el. Az utóbbi országcsoporton belül a legtöbb jel arra utal, hogy a Csehország, Lengyelország és Horvátország alkotta, valamint a Bulgáriát, Romániát, Magyarországot és Szlovákiát magában foglaló csoportok is elkülönülőben vannak egymástól a várható élettartam alakulása szerint.

Tárgyszavak: születéskor várható élettartam, klub-szemlélet, férfiak és nők, halandóság, Európa

Kovács Katalin, KSH Népességtudományi Kutatóintézet

E-mail:kovacs@demografia.hu 


\section{BEVEZETÉS}

A várható élettartamot egyre inkább az életminőség egyik legfontosabb komponensének tekintik. Az élettartam globális egyenlőtlenségeire vonatkozóan a ma legfrissebbnek számító átfogó ENSZ-jelentés a 2008-as évre azt állapította meg, hogy az életkilátások világszerte jelentősen közelítettek egymáshoz (United Nations 2012, Canning 2012, Goesling - Firebaugh 2004). A jelentés szerint az alapvetően konvergens tendenciáktól csupán két régióban volt eltérés tapasztalható: az élettartamok visszaesése jellemezte a szubszaharai országokat, az élettartamok a globálisnál jóval lassabb fejlődése pedig a kelet-európai országokat. Míg az első esetben a fejlemények elsősorban a HIV/AIDS járvánnyal voltak összefüggésbe hozhatók, addig a keleteurópai régió esetében a magyarázat kevésbé volt egyértelmü. Tanulmányunk témája ezért a kelet-európai országok születéskor várható élettartamainak alakulása, amelyet az Európa más országaiban mutatkozó trendekkel összehasonlítva mutatunk be.

Az egyes országokban mért várható élettartamok egymáshoz való közeledésének, azaz konvergenciájának, más szavakkal a halálozási viszonyok egységesülésének kérdése több tudományterület számára bizonyult izgalmas kutatási kihívásnak. Demográfiai kutatások számos, a közelmúltat jellemző konvergens és divergens (Rogers - Crimmins 2011) folyamatot azonositottak. A demográfiában a konvergencia jelentheti a kor-specifikus (Edwards - Tuljapurkar 2005, Vallin - Meslé 2009, Gillespie et al. 2014), illetőleg az ok-specifikus halálozási ráták mintázatának egységesülését (Meslé 2004). Ez a második megközelítés igen hasonló a népegészségügyi kutatások nézőpontjához. Népegészségügyi megközelítésben az ok-specifikus halálozás tanulmányozása mellett és azzal összefüggésben a különböző rizikófaktorok szerepe áll a középpontban (d’Albis et al. 2014), míg a közgazdasági elemzések homlokterében az a kérdés áll, hogy mely gazdasági folyamatok és makro-indikátorok befolyásolják legerősebben a várható élettartam alakulását.

A várható élettartamok alakulásával kapcsolatos szakirodalom jelentős része a globális trendeket vizsgálja: ennek bemutatására csak részlegesen és a középkelet-európai térségre vonatkozó megállapításokra koncentrálva nyílik lehetőségünk. A különféle, ma prosperáló irányzatok közül az úgynevezett klubszemlélet kialakulásának néhány fontos lépését ismertetjük.

Annak ellenére, hogy globális léptékben és a II. világháborút követő időszak egészére nézve a születéskor várható élettartam tekintetében legtöbben a kon- 
vergáló trendeket tartják dominánsnak, számos kutató a „klubszemlélet” híve. A „klubkutatók” az országok olyan csoportjait próbálják körülhatárolni, ameIyekben a várható élettartamok egyre közelebb kerülnek egymáshoz, miközben a különböző csoportokat jellemző átlagos vagy modális várható élettartamok egymástól divergálnak, vagy legalábbis a klubokon belüli változásokhoz viszonyítva kevésbé közelednek egymáshoz.

A „,klubszemlélet” első nagyhatású alkalmazója Mayer-Foulkes (2001, 2005) volt, aki a gazdasági növekedési elméletek analógiájára vizsgálta a várható élettartamok alakulását. Első tanulmányában az 5 éves intervallumokra átlagolt várható élettartamok eloszlásainak változását vizsgálta 1962 és 1997 között, 159 országra nézve. A születéskor várható élettartamok megoszlása mindkét időpontban jellegzetes bimodális mintázatot mutatott: a várható élettartamok mind az 1960-as évek elején, mind pedig az 1990-es évek végén két-két (az utóbbi időszakban nyilvánvalóan magasabb) érték körül sűrűsödtek -, de az 1990-es évek végén a korábbinál több ország várható élettartama csoportosult a magasabb modális érték körül. Ennek alapján a szerző három „pályát” feltételezett, amelyeket az egyes országok várható élettartamai bejárhatnak: vagy az 1960-as alacsonynak számító várható élettartam után az 1990-es évek végén is alacsonynak számító élettartamot értek el, vagy maradhattak a „magas - magas” klubban, illetve átkerülhettek az „alacsony élettartamúak” klubjából a „magas élettartamúak” klubjába. Egyszerü ökonómiai statisztikai eszközök segítségével igazolta, hogy a „három klub” modell pontosabban írja le az élettartamok fejlo”dését, mint az „egyetlen klub” vagy a „két klub” modell. Az elemzés eredményeit a három klub egy-egy tipikus országa által bejárt út szemléltetheti. A várható élettartam az „alacsony - alacsony” klubban az 1962-es 39,5 évről, 1997-re 48,2 évre, az „alacsony - magas” klubban az 1962-es 46,9 évről, 1997-re 64,9 évre, a „magas - magas” klubban pedig 65,4 évről, 74,1 évre emelkedett. Az elemzés az „egészségtőke” koncepcióját integrálja a közgazdaságtani „emberi tőke” koncepciójába, ugyanakkor - némiképp zavaróan - ez utóbbi eredményének is tekinti az előbbit. Az emberi tőke egyik legfontosabb összetevőjének tekintett technológiai innovációs szintben mutatkozó különbségek alapján a szerzőben felvetődött, hogy a „magas - magas” klubon belül további esetleges „alklubokat” lehetne körülhatárolni, amelyeket az eredmények grafikus megjelenítése is támogatott. Ez a felvetés kimondatlanul a kelet-európai és a közép-ázsiai országokra vonatkozott, amelyek ebben az elemzésben a „magas - magas” klubba kerültek, de azon belül viszonylag alacsony várható élettartammal rendelkeztek, ugyanakkor erre az elhatárolásra ebben a tanulmányban végül nem került sor. 
Komplikáltabb elemzéseket nélkülözve, csupán a várható élettartam alakulását vizsgálva, McMichael et al. (2004) szintén három országcsoportot különített el: azokat, amelyekben az 1950 és 2001 közötti időszakban a várható élettartam emelkedett, azokat ahol nem változott lényegesen, illetve azokat, ahol jelentősen visszaesett. Az utóbbi csoportba szinte kizárólag fekete-afrikai országokat tartoznak, míg a stagnálást mutató országok jellemzően kelet-európaiak. A jelentős mortalitásnövekedést mutató országok többségében az 1980-as évek elejéig a halandóság csökkenése (azaz a várható élettartam növekedése) töretlen volt, azt követően azonban zuhanásszerüen esett vissza: Ruandában például egyes években akár 25 évre is.

Bloom és Canning (2007) az előzőekben ismertetett elemzésekből kiindulva a klubokat mortalitási „rezsimeknek” tekinti, amelyekben a várható élettartam további fejlődését az addig elért élettartam függvényében matematikailag is megfogalmazható, de az egyes rezsimekben különböző törvények vezérlik. Ez a megközelítés érthetővé teszi, hogy miért volt 1960 és 2000 között a várható élettartam növekedése a kezdetben „közepesnek” számító várható élettartamú országokban a legnagyobb. A két rezsim matematikai leírásában a szerzők olyan modellt alkalmaznak, amely megengedi a rezsimváltás lehetőségét, de annak valószínűsége a megfigyelés kezdetén (az 1960-as évek elején) elért élettartamtól függ. Azokat az (ebben az esetben 1963-ra vonatkozó) élettartamokat, amelyekhez igen alacsony „,rezsimváltási valószínűség” tartozik, a „mortalitási csapdá”-t jelentő helyzeteknek tartották. A mortalitási csapda fogalmát a korábbi közgazdasági „,szegénységi csapda” analógiájára alkották meg. Ezekben a csapdahelyzetekben a várható élettartamok fejlődésének útjába éppen az alacsony várható élettartam áll, amelyből az érintett országok csak valamilyen „nagy lökés” segítségével szabadulhatnak ki. Fontos, hogy Bloom és Canning úgy vélte, hogy ilyen csapdahelyzetek a várható élettartam magasabb szintjein is előállhatnak, amikor például éppen a mortalitás relatív magas szintje (azaz az aránylag alacsony várható élettartam, illetve a viszonylag rossz általános egészségi állapot) okozhatja a termelékenységnövekedés visszafogottságát, amely viszont gátolja a várható élettartam további fejlődését. Ezeket a konkrét csapdahelyzeteket ugyanakkor nem írták le részletesen.

Az előző elemzésekre alapozva Wilson (2011) az élettartamfejlődés 1950 és 2010 között látható trendjei alapján öt régióra osztotta a világot. Ez a felosztás nem alapoz részletes matematikai elemzésre, hanem inkább a várható élettartam fejlődésére nézve - a korábbi elemzések alapján - fontosnak tekinthető tényezők számbavételére. Ennek alapján egy koherens összképet nyújtó kategorizáció jött létre: az öt blokkba tartozó országok egymástól jellegzetesen 
különböző utakat jártak be a várható élettartam alakulását tekintve. Az öt különböző régió a következő volt: a volt Szovjetunió utódállamai, a fejlett világ más országai, Dél-Afrika, a szubszaharai térség más országai, illetve az egyéb fejlődő országok. Ebben a csoportosításban a kelet-közép-európai országok az egyéb fejlett országok kategóriába kerültek, bár a szerző megjegyezi, hogy ezekben az országokban a várható élettartam alakulása sok tekintetben közös jegyeket mutat a szovjet utódállamokban tapasztaltakkal.

A várható élettartam klubszerű elrendeződése a gazdasági természetű elemzésekben is megjelenik, az ott feltételezett összefüggésekből szerves módon következően. A születéskor várható élettartam és az egy före jutó nemzeti jövedelem közötti kapcsolatot elsőként Preston (1975) írta le klasszikusnak tekinthető tanulmányában. Ebben a kutatásban a két változó keresztmetszeti értékeit öszszehasonlítva arra jutott, hogy a magasabb nemzeti jövedelmekhez sztochasztikusan magasabb várható élettartam tartozik, ugyanakkor a magasabb jövedelmek esetében a jövedelem további növekedése már kevesebb hozadékkal jár a várható élettartamot tekintve. Ugyanezt az összefüggést az 1960-as és a 2000-es évre nézve összehasonlítva az volt látható, hogy 2000-ben a magasabb várható élettartamot már alacsonyabb nemzeti jövedelem mellett is el lehetett érni (Casabonne-Kenny 2012). Hum és szerzőtársai (2012), valamint Edwards (2010, 2011) azonban a mellett érvelnek, hogy a felszínen megjelenő trendeket valójában két, meglehetősen különböző mechanizmus alakította ki: véleményük szerint más hatásokat tükröz a csecsemő- és kisgyermekkori halandóság alakulása, mint a felnőttkori mortalitásé. Míg az elsőre olyan tényezők hatnak, amelyek egyre alacsonyabb nemzeti jövedelem mellett is megjelenhetnek, a felnőttkori mortalitásra ugyanez nem igaz. Mindennek alapján úgy vélik, hogy a közeljövőben a várható élettartamok vonatkozásában a divergens tendenciák válnak majd dominánssá, tükrözve az országok közötti jövedelmi egyenlőtlenségek növekvő tendenciáit.

A közgazdasági orientációjú elemzésekben a klubszemlélet továbbgyűrüzött az általános, a globális fejlődés irányait, illetve konvergenciáját vizsgáló irányzatok felé. A teljesség igénye nélkül említjük meg Vollmer és szerzőtársai (2013) munkáját a várható élettartam, az iskolázottság, illetve a nemzeti jövedelem együttes eloszlásainak vizsgálatáról, ahol az 1960-ban detektálható két „fejlettségi klub” helyett 2000-re három fejlettségi klub kialakulását valószínüsítették, illetve Lehmijoki (2009) elemzését, amely négy fejlettségi klubot különített el. Ez utóbbi, regressziós fa módszerü elemzésében a várható élettartam mellett a nemzeti jövedelem, az írni-olvasni tudás rátája, a fertilitásváltozás rátája, illetve az AIDS fertőzöttségi ráta szerepel. 
A demográfusok körében viszont egyáltalán nem egyértelmủ az élettartamok konvergenciájának, de még a klubelméleteknek támogatottsága sem. A „klubszemlélet” megjelent ugyan korai klasszikus demográfiai munkákban: a latin-amerikai országok várható élettartamainak történeti távlatban való vizsgálata során például Arriaga és Davis (1969) világosan megkülönböztették a latin-amerikai országok két csoportját: azokat a történeti távlatban szegényebb országokat, ahol az 1930-as évekig a várható élettartam igen alacsony volt, valamint azokat a fejlett országokat, ahol a várható élettartam már 1930 körül is igen magas volt. 1930-at követően hasonló tempójú fejlődést tapasztaltak az országok két csoportjában. A klubszemlélet elfogadottsága azonban nem vált általánossá.

A demográfusok és a népegészségügyi szakemberek inkább a divergens tendenciák bemutatására helyezik a hangsúlyt (például Glei et al. 2010, GoliArokiasamyb 2014), bár ezekben az esetekben elsősorban nem a születéskor várható, hanem más élettartamok, illetve kor-specifikus halálozási mutatók álltak a középpontban. Ugyanakkor McMichael és szerzőtársaiéhoz hasonló eredményre jutott a várható élettartam trendjeinek leíró vizsgálata alapján Meslé és Vallin $(2004,2011)$ is, a növekvő, stagnáló és visszaeső várható élettartamú országok csoportját különítve el. A visszaeső élettartamú országok körét vizsgálva megállapítják, hogy ebbe a helyzetbe nem csupán az AIDS/HIV epidémiától sújtott országok kerültek, hanem azok is, amelyek súlyos háborús időszakokon mentek keresztül. E példák alapján Meslé és Vallin a determinisztikus szemlélet ellen érvel: az egyes országokban a várható élettartamot szerintük számos egyedi történeti körülmény is erősen befolyásolja. Ez utóbbi elemzésben a közép- és kelet-európai régió ugyanakkor egységesen stagnáló élettartamú tömbként jelenik meg.

Az élettartamok konvergenciájának, illetve divergenciájának kérdését természetesen nem csupán a klubszemlélet keretein belül vizsgálták. Moser és szerzőtársai (2005) egy diszperziós indikátor használatát javasolta, amely figyelembe veheti az egyes országokban a várható élettartam alakulása mellett az országok népességének nagyságát is. Saját újonnan kifejlesztett diszperziós indikátoruk alkalmazásával az 1950 és 2000 közötti időszakot vizsgálva úgy találták, hogy az élettartamok konvergenciájának az 1980-as évekig tartó szakaszát a divergencia időszaka követte. A divergenciát „okozó”, azaz az 1980-as évek második felétől visszaeső várható élettartamú országok csoportját tekintve (ide összesen 24 ország tartozott a vizsgált 153-ból) ők is elsősorban szubszaharai országokat, néhány ázsiai országot (Irak, Észak-Korea), illetve a szovjet utódállamokat azonosították. 
Az európai tendenciák vizsgálata során Kelet-Európa gyakran egyetlen, közös jellemzőkkel rendelkező országcsoportként jelent meg, amelyben a halandóságot általában véve stagnálás, illetve a Szovjetunió szétesését követő időszakban halálozási válság, majd igen lassú fejlődés, ugyanakkor belső divergencia jellemzi (Safaei 2012, Mackenbach 2013). Ebben, illetve leíró szempontból a főbb haláloki trendeket illetően egyetértés mutatkozik a népegészségi és a demográfus szakma között: mindkét esetben a szív- és érrendszeri betegségek, valamint a külsődleges halálok okozta halálozás a nyugat-európaihoz képest jóval magasabb szintje, illetve nem eléggé dinamikusan csökkenő trendjei miatt alakult ki ez a lényeges törésvonal (Helis et al. 2010). Néhány kurrens elemzés azonban megkérdőjelezte a „kétosztatú” Európa képét. Napjainkra már „háromosztatú” Európa-kép is kialakult: a magas várható élettartamú nyugat-európai országok és az alacsony élettartamú kelet-európai országok között a „közepes” várható élettartamú közép-kelet-európai országok csoportját különböztetve meg (Luy et al. 2011). Az imént idézett tanulmány ugyan nem a születéskori, hanem a 15 éves korban várható élettartamokra vonatkozott, de legtöbb megállapítása a születéskor várható élettartamokra is érvényesnek tünik.

Tanulmányunkban arra keressük a választ, hogy a legfrissebb adatok fényében a kelet-európai és a közép-kelet-európai országok vajon „egy klubba” tartoznak-e, avagy a korábban felfedezett divergens tendenciák folytatódtak, azaz ezek az országok napjainkban is egyre távolabb kerülnek-e egymástól a születéskor várható élettartalmat tekintve, más szóval, hogy két vagy több „klub” létrejöttét érdemes feltételezni Európában. Ez a kérdés természetes módon egészül ki a közép-kelet-európai országok, ezen belül a magyarországi és a nyugat-európai várható élettartamok közötti szakadék alakulására vonatkozó kérdésekkel. Módszertanilag az eddig bemutatott két véglet között keressük a választ. A sok országot magukba foglaló és függvényszerü kapcsolatot kereső elemzések, illetve a várható élettartamok szinte egyedi vizsgálatához kapcsolódó, gyakran egyedi interpretációnak is teret engedő, csupán számszerű különbségeket, esetleg egyszerü szóródási mutatókat alkalmazó elemzési eszközök közötti középútként választottuk a trendelemzést. Ez a módszer lehetővé teszi az egyes országokban a várható élettartam alakulásában mutatkozó dinamikák matematikailag megalapozott összehasonlítását anélkül, hogy a várható élettartamok alakulása mögötti általános törvényszerüségek megállapítását célozná. 


\section{ADATOK ÉS MÓDSZEREK}

Ebben a tanulmányban Magyarország és a Magyarországhoz történeti, földrajzi vagy társadalmi értelemben hasonló országok várható élettartamainak alakulása áll érdeklődésünk középpontjában. Az adatforrás kiválasztása egyrészt azt a célt szolgálta, hogy minél több ilyen ország, minél hosszabb időszakra vonatkozó adatai szerepelhessenek elemzésünkben, másrészt azonban elemzésünk módszeréhez is igazodott. A módszer kiválasztásával elsősorban azokra a korábbi tapasztalatokra reflektáltunk, amelyek egymásnak kismértékben ellentmondó eredményekkel szolgáltak, köszönhetően az elemzési időszak, vagy az azon belül figyelembe vett élettartamok némiképpen tetszőleges kiválasztásának, avagy az elemzésbe bevont országok (általában adathiányból fakadó) szelektivitásának (Raskina - Tsyplakova 2014). Figyelembe vettük azokat a tapasztalatokat is, amelyek azt mutatták, hogy a várható élettartamok alakulásánál időben is jelentősen változó dinamikákra lehet számítani. Ezeknek a buktatóknak az elkerülését a trendelemzés eszközeivel láttuk a leginkább megvalósithatónak.

Az adatbázis kiválasztásakor azt is szem előtt tartottuk, hogy a nemzetközi adatbázisok esetében szükségszerủen jelentkező időbeli késés a lehető legrövidebb legyen. Ezért a sok lehetséges jó minőségű adatbázis közül azt részesítettük előnyben, amely az élettartamok alakulásáról a legfrissebb adatokat szolgáltatja, és amely nem pótolja a hiányzó adatokat valamiféle feltételezett trendeken alapuló becslésekkel. Ezért választottuk a WHO Európai Régiójának mortalitási adatbázisát, ezen belül is a „Health for All” adatbázist', amely ugyan csak 1970 óta gyűjt adatokat, de az európai országokra nézve a legfrissebb adatokkal rendelkezik. Az adatbázisba kevés kivétellel a kor-specifikus halálozási ráták kerülnek be, amelyekből a WHO egységes módon készíti el a várható élettartamok becslését. Az adatbázisban szereplő adatsorok nem minden esetben teljesek, azokra az évekre nézve adathiányosak, amikorra az országok nem szolgáltattak adatokat. Ugyanakkor a választott módszerre való tekintettel, egy alkalommal adatkizárásra is sort kellett keríteni (Örményország 1988), mivel abban az évben elsősorban az országot sújtó különösen nagyerejü földrengés miatt a halálozás kiugróan magas volt (a várható élettartam, ennek megfelelően, 10 évvel esett vissza), de ennek a természeti katasztrófának a hatásai a következő évben már nem voltak jelen.

\footnotetext{
'European health for all database (HFA-DB), http://data.euro.who.int/hfadb/ Letöltés: 2016. január.
} 
Minthogy a trendelemzés azt célozta meg, hogy a lehető legnagyobb mértékben támaszkodjon reális adatokra, az elemzést csak azokra az összefüggő időintervallumokra nézve végeztük el, amelyekben az adathiány minimális volt. Így az elemzett időszak hossza számos országban jelentősen megrövidült, ugyanakkor az elemzés eredményeit illető bizonytalanság csökkent. Az idősorokat általában akkor tekintettük folyamatosnak, azaz elemzésre alkalmasnak, ha egy hosszabb időszakra nézve minden évre rendelkezésre álló várható élettartam sorában mindössze egyetlen hiány volt található. Kivételt két esetben (Portugália, Olaszország) tettünk, amikor, két egymást követő évet kivéve, a most áttekintett időszak szinte teljes egészére nézve rendelkezésre álltak az adatok, és az adathiányos évek nem a teljes elemzési periódus elején vagy végén helyezkedtek el. Az elemzésre alkalmasnak minősített időszakok hosszát és határait az 1. táblázatban mutatjuk be.

Az adatelemzést a Jointpoint Regression Program 3.5.1-es verziójával végeztük el, amely az amerikai National Institutes of Health Division of Cancer Control and Populations Sciences szabad felhasználású szoftvercsomagja². A csomag idősorokra nézve a lehető legegyszerübb, azaz a lehető legkevesebb töréspontból álló modell illesztésére alkalmas. A töréspontok olyan időperiódusokat választanak szét, amelyekre nézve az idősorok - különféle - lineáris szakaszokkal jellemezhetők. A program abból a feltételezésből indul ki, hogy az adatsor 0 töréspontú lineáris modellel jellemezhető, és ehhez képest vizsgálja az 1 törésponttal rendelkező modelleket. Ha a Monte Carlo-módszeren alapuló permutációs teszt segítségével az 1 törésponttal rendelkező modellt jobbnak találja, akkor lehetőség nyílik annak vizsgálatára is, hogy a 2, 3 stb. törésponttal rendelkező modellek vajon jobbak-e, mint a náluk kevesebb törésponttal rendelkezők (Kim et al. 2000).

A program a hiányzó értékeket a létező adatpontokra illesztett regressziós értéknek megfelelő értékként kezeli, de ha ezek száma nagy, akkor a becslés jelentősen módosulhat és bizonytalanabbá válhat. Ez a tény indokolta a fentiekben vázolt, viszonylag szigorú eljárást a hiányzó értékekre vonatkozóan. A program beállításai során a lehetséges töréspontok számát a hosszabb idősorok esetében 4-ben, a rövidebb idősorok esetében 3-ban maximáltuk, amely alól csak egyetlen esetben tettünk kivételt. Ugyanakkor azt is figyelembe vettük, hogy a program által optimálisként kiválasztott modell sok esetben túl tág megbízhatósági intervallumokat szolgáltatott a töréspontok időben való elhelyezkedésére nézve. Megbízhatatlannak tekintettük azokat az eredményeket, ahol egy vagy több töréspont időbeli elhelyezkedése nagyon bizonytalan volt, például egy 10 év hosszúságú megbízhatósági intervallumban helyezkedtek el.

\footnotetext{
2 Joinpoint Trend Analysis Software, Version 3.5. 1, http://surveillance.cancer.gov/joinpoint/ Letöltés: 2016. január.
} 
1. táblázat: Az elemzésben szereplő országok, az elemzett időszak hossza, illetve az elemzés első eredményei: a töréspontok optimális száma

List of countries included in the analysis, the length of periods analysed and the optimal numbers of turning points

\begin{tabular}{|c|c|c|c|c|c|}
\hline \multirow{2}{*}{ Ország } & \multirow{2}{*}{ Időszak } & \multirow{2}{*}{$\begin{array}{l}\text { Elemzett időszak } \\
\text { hossza, év }\end{array}$} & \multirow{2}{*}{ Adathiány } & \multicolumn{2}{|c|}{ Töréspontok optimális száma } \\
\hline & & & & férfiak & nők \\
\hline Örményország & $1970-2003$ & 34 & $1988^{a}$ & 3 & 2 \\
\hline Ausztria & $1970-2014$ & 45 & & 4 & (1) \\
\hline Belgium & $1970-2012$ & 43 & & 2 & 1 \\
\hline Bulgária & 1971-2013 & 43 & & 2 & 2 \\
\hline Csehország & $1971-2013$ & 43 & 1985 & 2 & 1 \\
\hline Dánia & $1970-2012$ & 43 & & 1 & 2 \\
\hline Finnország & $1970-2013$ & 44 & & (2) & 2 \\
\hline Franciaország & $1970-2011$ & 42 & & 2 & 2 \\
\hline Görögország & $1970-2012$ & 43 & & 1 & (1) \\
\hline Magyarország & $1970-2013$ & 44 & & 4 & 1 \\
\hline Izland & $1971-2009$ & 39 & & 0 & $(1)$ \\
\hline Írország & $1970-2012$ & 43 & & 3 & (1) \\
\hline Izrael & $1970-2013$ & 44 & & 1 & 0 \\
\hline Olaszország & 1970-2012 & 43 & 2004, 2005 & 1 & (2) \\
\hline Kirgizisztán & 1970-2011 & 42 & & 3 & 3 \\
\hline Lettország & $1970-2012$ & 43 & & 4 & 2 \\
\hline Litvánia & $1970-2012$ & 43 & & 5 & 4 \\
\hline Luxemburg & $1970-2013$ & 44 & & 1 & 0 \\
\hline Málta & $1970-2014$ & 45 & & 2 & 2 \\
\hline Hollandia & $1970-2013$ & 44 & & 2 & 3 \\
\hline Norvégia & $1970-2013$ & 44 & & 4 & 4 \\
\hline Lengyelország & $1970-2013$ & 44 & & 1 & 2 \\
\hline Portugália & $1970-2013$ & 44 & 2014, 2015 & 0 & 1 \\
\hline Románia & $1970-2012$ & 43 & & 2 & 2 \\
\hline Oroszország & 1970-2011 & 42 & & 4 & 3 \\
\hline Spanyolország & $1970-2013$ & 44 & & 3 & (2) \\
\hline Svédország & $1970-2013$ & 44 & & (3) & (1) \\
\hline Svájc & $1970-2013$ & 44 & & (1) & 1 \\
\hline Ukrajna & $1970-2012$ & 43 & & 4 & 3 \\
\hline Egyesült Királyság & $1970-2013$ & 44 & & 2 & (1) \\
\hline Üzbegisztán & $1970-2005$ & 36 & & 4 & 3 \\
\hline Azerbajdzsán & $1985-2004$ & 20 & & 3 & 3 \\
\hline Fehéroroszország & $1985-2009$ & 25 & 2006 & 3 & 3 \\
\hline Horvátország & $1985-2013$ & 29 & & 1 & 3 \\
\hline Esztország & $1985-2011$ & 27 & & 2 & 1 \\
\hline Grúzia & $1985-2014$ & 30 & 1993, 2008 & 3 & 2 \\
\hline Németország & 1990-2013 & 24 & & 1 & (3) \\
\hline Kazahsztán & $1985-2012$ & 28 & & 3 & 3 \\
\hline Montenegró & $1985-2009$ & 25 & 1998, 1999 & 3 & $\begin{array}{l}2 \\
7\end{array}$ \\
\hline Moldova & 1985-2013 & 29 & & 3 & 3 \\
\hline Szerbia & $1998-2013$ & 16 & & 0 & 0 \\
\hline Szlovákia & $1984-2010$ & 27 & & 3 & (3) \\
\hline Szlovénia & $1985-2010$ & 26 & & 1 & (3) \\
\hline Tádzsikisztán & $1985-2005$ & 21 & & 3 & 3 \\
\hline Macedón Köztársaság & 1991-2010 & 20 & & 0 & 0 \\
\hline EU-15 & $1970-2013$ & 44 & & 2 & 3 \\
\hline
\end{tabular}

Forrás: WHO Health for All Database.

Megjegyzés: a Elemzésből kizárt. 
Mindezeken felül a vizsgálathoz szükséges annak meghatározása is, hogy milyen hosszú lehet minimálisan az a periódus, amelyet még különálló szakasznak tekinthetünk. Az elemzést többféle - a józan ész által szabott határokon belüli - hosszúságú időperiódussal is elvégeztük (4, 5, illetve 6 évvel). Az eredmények nem különböztek egymástól jelentősen, viszont a megbízhatóságuk (a töréspontok időben való elhelyezkedésére kínált becsléseket értve ez alatt) igen, így a „legmegbízhatóbb” eredményeket kínáló variációt választottuk ki. A történeti perspektíva, illetve a matematikai racionalitás a hosszabb időszak használata mellett szólt volna, ugyanakkor a rövidebb periódusok lehetőségének fenntartása mellett is szóltak érvek. Ezek közül a legfontosabb az volt, hogy számos, az elemzésünk körébe vont ország tapasztalt meg mortalitási krízisperiódusokat, amelyek sokszor rövid ideig tartottak, és amelyeket hasznosabbnak tűnt elkülöníteni az azokat követő időszakokat jellemző trendektől.

Az elemzésbe minden olyan országot bevontunk, amely a WHO Európai Régiójában helyezkedik el. Országcsoportok adatait nem használtunk, kivéve az EU-15 országcsoportra vonatkozót, amelyet egyfajta referenciaszintként alkalmaztuk. Összességében 31 országra nézve legalább 30 éves periódusra, valamint 15 országra nézve ennél rövidebb időszakra nyertünk adatsorokat. A férfi és női élettartamokat külön vizsgáltuk. Így összesen 92 adatsort vizsgáltunk meg, amelyből a trendelemzés 14 esetben hozott igen bizonytalan eredményt. A fennmaradó 78 adatsor esetében azonban a trendelemzés eredményei jól megalapozottnak tekinthetők. Az elemzés során a legjobbnak tekinthető felbontásban talált töréspontok számát az 1. táblázatban összegeztük, ezek közül a bizonytalan eredményeket zárójelben, dőlt betűvel tüntettük fel.

\section{EREDMÉNYEK}

A trendelemzés eredménye minden idősorra vonatkozóan egy szekvencia, amely az egymást követő (az elemzés által elkülönített) időintervallumokban a várható élettartam változását leíró lineáris trendek meredekségeinek egymásutánja. Az eredményeket az M1-M4 táblázatokban (lásd a tanulmány mellékletét) öszszegeztük. A meredekségek önmagukban is szemléletes jelentést hordoznak: az egy év alatt elért életév-nyereség nagyságát mutatják. Egy 0,33-os meredekséggel jellemezhető korszakban például a várható élettartam évenként 0,33 évvel, azaz 3 évente egy évvel nő. 
Számos, az élettartamok alakulására vonatkozó elemzésben a kutatók automatikusan külön csoportba sorolják a nyugat- és a kelet-európai országokat. Ebben az elemzésben ez nem automatikusan történt meg, az élettartamok csökkenő, stagnáló, illetve növekvő szakaszainak sorozatait vizsgálva azonban mégis azt állapítottuk meg elsőként, hogy a tág értelemben vett nyugat-európai országokban a várható élettartam valóban jellegzetes, a többi országokétól különböző pályát járt be - ezekben az országokban 1970 óta nem fordult elő olyan időszak, amelynek során a születéskor várható élettartamok számottevő mértékben visszaestek volna (lásd az M7-M4 táblázatokat a tanulmány mellékletében). Mindemellett a nyugat-európai országokban a fejlődést nem hozó, stagnáló periódusok is ritkák voltak, és amennyiben mégis előfordultak, nem nyúltak 10 évnél hosszabb időszakra. A közép-kelet-európai, a közép-ázsiai, a balti, valamint a balkáni országok esetében viszont éppen az efféle fejlődési pálya tekinthető kivételesnek. Azon nem nyugat-európai országok döntő többségében, amelyekre nézve hosszú adatsorokkal rendelkezünk, előfordult a várható élettartam kisebb-nagyobb mértékü visszaesése, és/vagy az élettartam hosszú ideig tartó stagnálása. A visszaesés mértéke azonban, mint ahogyan ezt a későbbiekben majd láthatjuk, igen különböző volt, és jelentősen befolyásolja a várható élettartam közelmúltbeli szintjének alakulását is.

Elsőként a férfiakat vizsgálva a különösen fejlett országok körében (amelyeket a továbbiakban nyugat-európainak nevezünk, bár körükbe soroltuk például Izraelt is) az alapvető tendencia valóban az élettartamok sokat emlegetett konvergenciája. A trendelemzés által kínált modellezett értékek szerint 1971-ben a legalacsonyabb férfi várható élettartam 64,4 év (Portugáliában) volt, szemben a legmagasabb, 72,1 évvel (Svédországban). 2013-ban a legalacsonyabb érték 77,6 év (Portugáliában) volt, míg a legmagasabb, 81,3 év (Svájcban). Az élettartamok terjedelme tehát az 1971-es 7,7 évről, 2013-ra 3,7 évre csökkent (1. ábra). Az általános konvergencia jelensége és a visszaesés nélküli fejlődés mellett ezekben az országokban sem „arányos” időbeli fejlődés volt megfigyelhetö, és a következőkben azt is bemutatjuk, hogy az sem bizonyult általános érvényű törvénynek, hogy a várható élettartam azokban az országokban fejlődik lassabban, ahol korábban alacsonyabb szinten volt.

A nyugat-európai férfiak várható élettartamának átlaga az egész periódus soránaz egymáshozigen közel eső francia és egyesült-királyságbeliférfiak várható élettartamai között mozgott. Ehhez az átlaghoz képest a most figyelembe vett időszak kezdetén jóval magasabb élettartamokat lehetett megfigyelni Dániában, Görögországban, Norvégiában és Hollandiában. Ezek az országok később „relatív lemaradók” lettek; legtöbbjük a most áttekintett időszak vége felé már 
„csak” az EU-15 átlaga körüli értékekkel rendelkezett, illetve Dánia a rangsor végére került. A „relatív lemaradók” mellett egy „felzárkózó” csoport formálódását is megfigyelhetjük, amelyek közül Portugália és Finnország, valamint Málta teljesítménye a leginkább szembeötlő. Finnország és Málta mellett azonban 1970 körül az EU-15-ös átlag alatti férfi várható élettartammal rendelkezett még Ausztria, Belgium, Luxemburg és Írország is, de a 2010-es évek elejére már ezekben az országokban is az EU-15 átlagához hasonló szintre emelkedett. Megszorításokkal idesorolható (az egyesült) Németország is, ahol a várható élettartam alakulását értelemszerüen csak az 1990-es évek elejétől kezdődően követhetjük nyomon. Ekkor a várható élettartam az EU-15 átlagánál alacsonyabb volt, a 2000-es évek első évtizedére azonban ez a különbség eltűnni látszik.

1. ábra: A férfiak születéskor várható élettartamának alakulása néhány nyugat-európai országban (a trendelemzés segitségével modellezett értékek)

Evolution of male life expectancy at birth in some Western European countries (modelled values based on trend analysis)

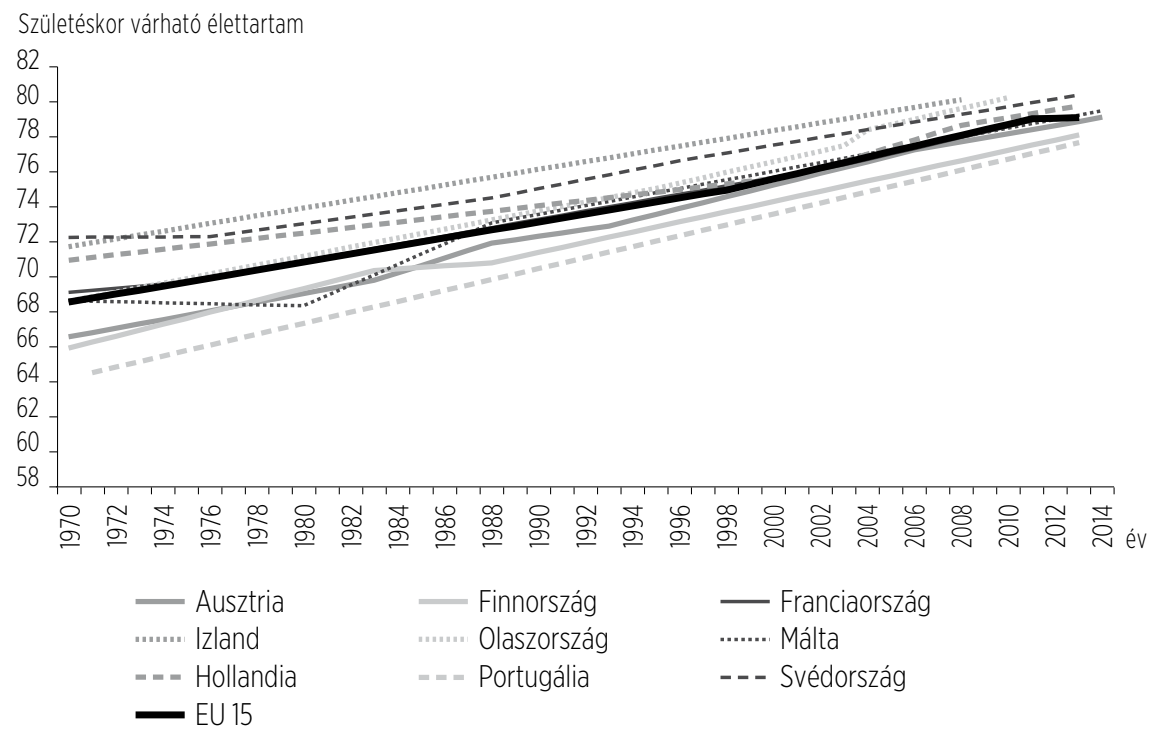

Forrás: European Health for All Database (HFA-DB) adatai alapján a szerző számításai.

Az eddigiekben bemutatott kép (átlag körüliek, az átlagnál magasabb értékkel kezdő, majd lemaradó, illetve felzárkózó országokból álló EU-15) nem különbözik az „egységesülő Európa” jól ismert képétől. Érdemes ugyanakkor megjegyezni, hogy a tág értelemben vett nyugat-európai országok között van egy az 
átlagnál végig jóval magasabb életkilátásokat mutató „elit klub” is, amelyet a férfiaknál Izland, Svájc, Svédország, illetve Izrael alkot, és amelyben a férfiak várható élettartama mindvégig jóval magasabb az európai átlagnál. Ehhez a klubhoz 1970 és 2013 között csak Spanyolország és Olaszország tudott csatlakozni.

2. ábra: A férfiak születéskor várható élettartamának alakulása néhány közép-kelet-európai és balkáni országban (a trendelemzés segitségével modellezett értékek)

Evolution of male life expectancy at birth in some Eastern European countries (modelled values based on trend analysis)

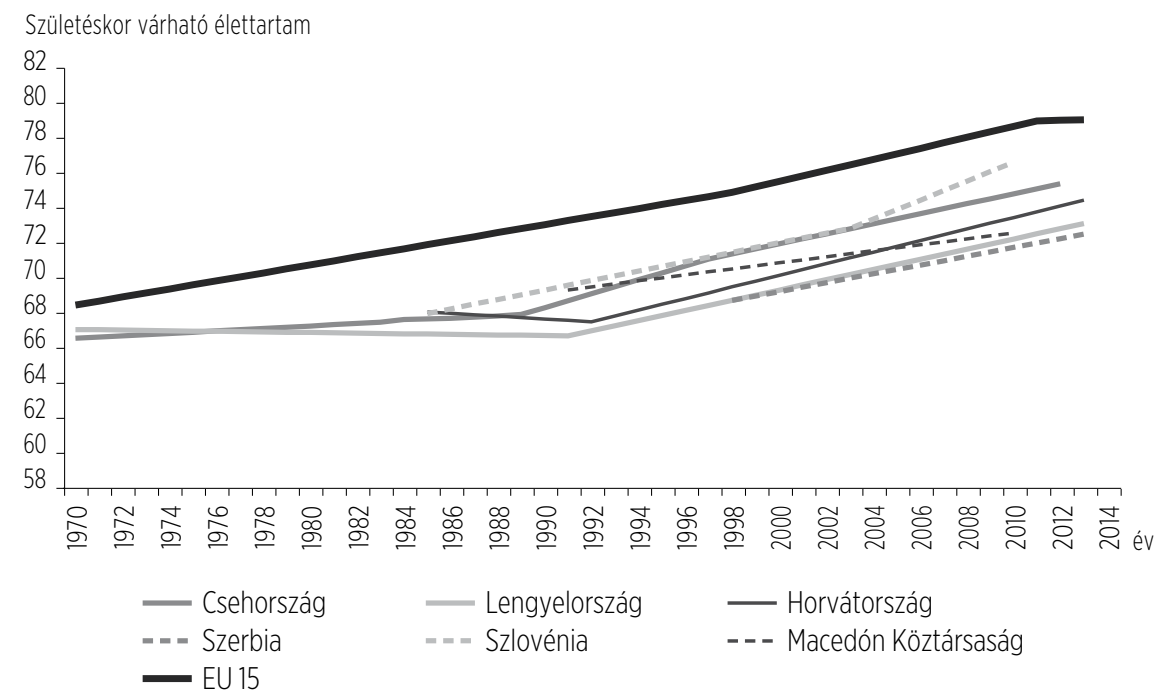

Forrás: European Health for All Database (HFA-DB) adatai alapján a szerző számításai.

Míg a tág értelemben vett nyugat-európai országokban ritkán fordult elő a férfiak várható élettartamának stagnálása vagy kismértékủ visszaesése, Európa más országaiban ez gyakran előfordult. A nem nyugat-európai országok közül ugyanakkor kivétel volt ez alól Lengyelország és Csehország: az előbbiben kismértékü, de egy évet meg nem haladó, lassú romlás volt csak tapasztalható az 1970-es évek során, míg az utóbbiban ugyanezen időszakban a férfiak várható élettartama igen visszafogottan ugyan, de nőtt (2. ábra). Az 1980-as évek végén csupán kismértékủ élettartamromlást tapasztalt meg Horvátország is (bár itt az 1986-ot megelőző időszakra vonatkozó adatok hiánya nem zárja ki egy nagyobb, korábban elszenvedett romlás lehetőségét), illetve nem mutatkoznak stagnációs vagy viszszaesési szakaszok néhány más olyan ország esetében sem, amelyek szintén csak 
az 1980-as évek közepétől, vagy még későbbi időponttól fogva közölnek adatokat: Azerbajdzsán, Szerbia, valamint Szlovénia tartozik e körbe. Ezekben az országokban ezt az enyhén romló, vagy nagyon kismértékű növekedést hozó időszakot a várható élettartam dinamikus növekedésével jellemezhető szakaszok követték.

3. ábra: A férfiak születéskor várható élettartamának alakulása néhány kelet-közép-európai országban (a trendelemzés segitségével modellezett értékek)

Evolution of male life expectancy at birth in some East Central European countries (modelled values based on trend analysis)

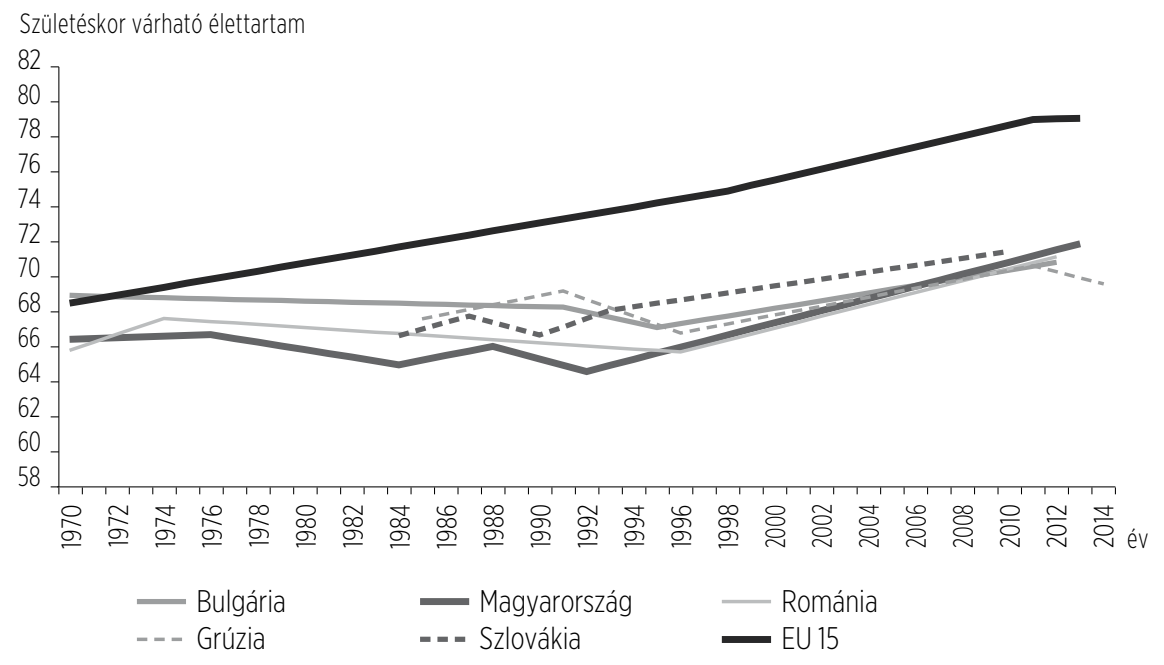

Forrás: European Health for All Database (HFA-DB) adatai alapján a szerző számításai.

A nem nyugat-európai országok egy másik csoportjában (3. ábra) az életkilátások az 1970-es és az 1980-as évtized során megfigyelhető lassú romlását, az 1980-as és az 1990-es évek fordulója körül a férfi születéskor várható élettartam további mérsékelt (1-2 éves), folyamatos visszaesése követte - erre a jelenségre a csökkenés mértékétől függetlenül halálozási válságként utalunk majd a későbbiekben -, majd az életkilátások mérsékelt, de stabil növekedése kezdődött meg. Az országok e csoportjába tartozik Bulgária, Szlovákia, Magyarország, Románia, valamint Grúzia is (bár az adatok Grúzia esetében csak 1985-től állnak rendelkezésre, és ott az 1980-as évek utolsó éveiben a várható élettartam emelkedett). Fenntartásokkal ugyan, de idesorolhatjuk Üzbegisztánt is, ahol viszont a várható élettartam nem elsősorban az 1990-es évek elejét jellemző halálozási válságperiódusban romlott, hanem azt jóval megelőzően, az 1970-es és az 1980-as évek 
első fele során, amely időszakban az 1970-ben még az EU-15 szintjén lévő üzbég férfi várható élettartam 6 évvel csökkent.

4. ábra: A férfiak születéskor várható élettartamának alakulása néhány balti és kelet-európai országban (a trendelemzés segitségével modellezett értékek)

Evolution of male life expectancy at birth in some Baltic and Eastern European countries (modelled values based on trend analysis)

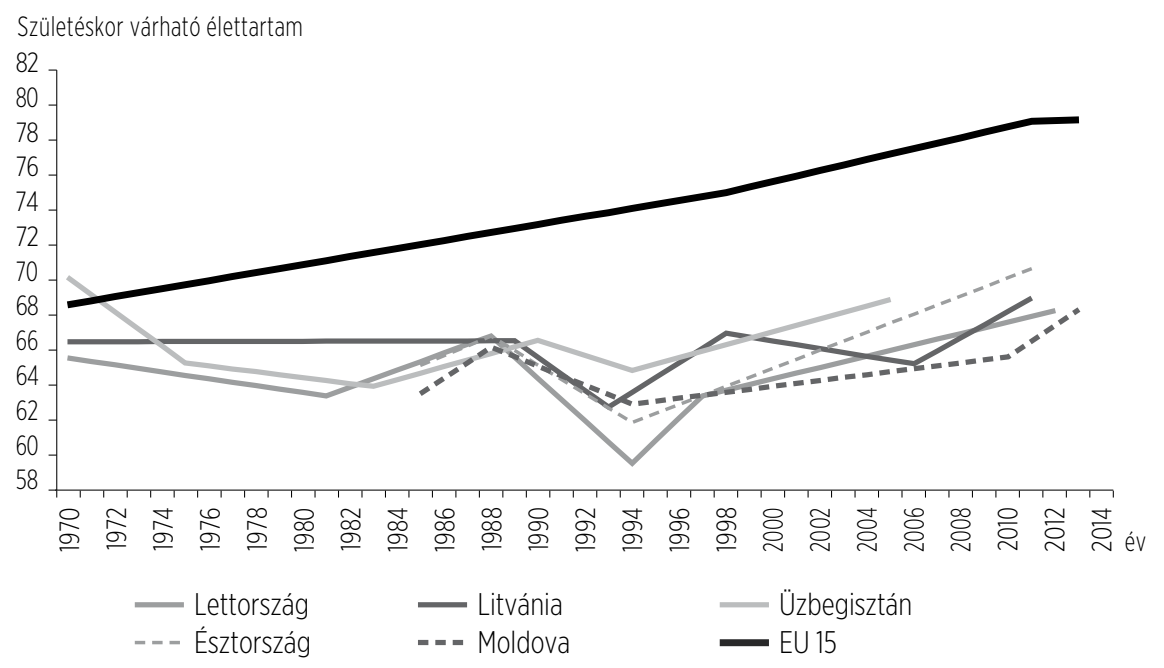

Forrás: European Health for All Database (HFA-DB) adatai alapján a szerző számításai.

Külön csoportba soroltuk azokat a mély halálozási válságot megélt országokat (4. ábra), amelyekben a válságot a férfi várható élettartamok különösen gyors fejlődése követte. Ezek az országok döntő többségükben volt szovjet tagköztársaságok: idetartozik Lettország, Litvánia, Észtország, de Moldova is. Litvánia ugyanakkor e minta egy sajátos variációját mutatja: itt az élettartam gyors fejlődését a 2000-es évek első felében egy rövidebb visszaesési szakasz szakitotta meg.

Az országok negyedik csoportjába azokat az országokat sorolhatjuk, ahol a mély (5-6 éves visszaesést jelentő) halálozási válságot a várható élettartam stagnálása, vagy kismértékủ további romlása, esetleg igen mérsékelt javulása követte (5. ábra). Ezekben az országokban a 2000-es évek közepén kezdődött meg egy nagyon dinamikus növekedési periódus, amely bizonyos országokban (Oroszország, Ukrajna, Kazahsztán) nagyon határozott, más esetben (Fehéroroszország) bizonytalanabb. 
5. ábra: A férfiak születéskor várható élettartamának alakulása néhány kelet-európai országban (a trendelemzés segitségével modellezett értékek)

Evolution of male life expectancy at birth in some Eastern European countries (modelled values based on trend analysis)

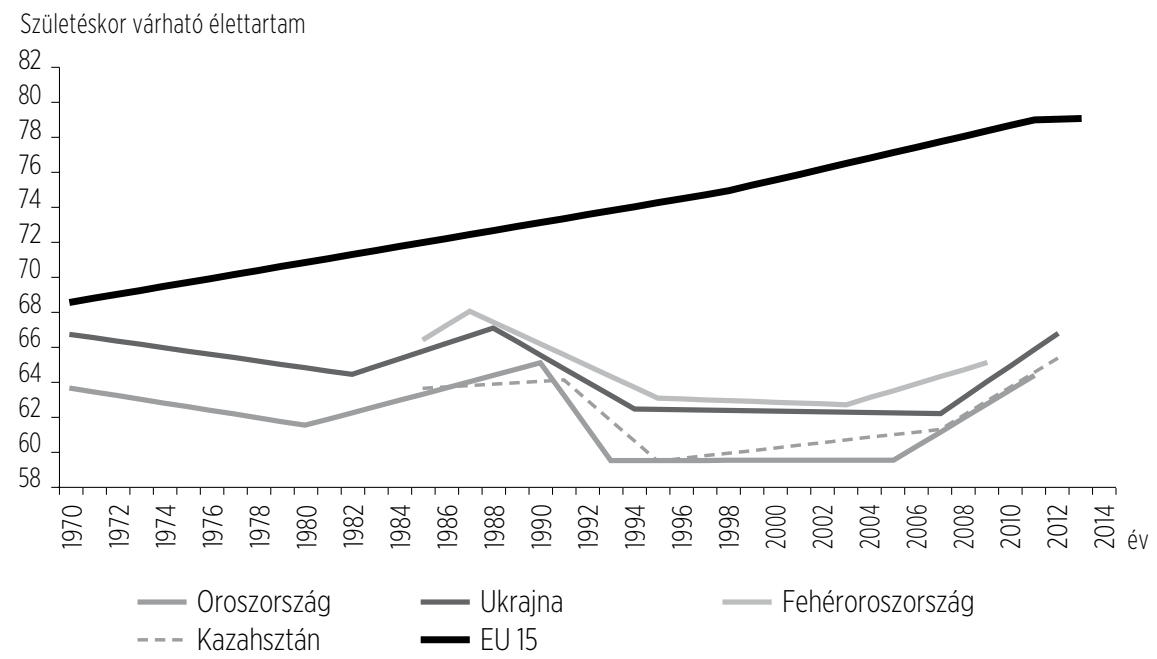

Forrás: European Health for All Database (HFA-DB) adatai alapján a szerző számításai.

Néhány országban nem lehetett jellegzetes mintázatokat megállapítani, ezekben a férfiak várható élettartama többé-kevésbé stagnálónak tekinthető (Örményországban 70, míg Kirgizisztánban 65 év körüli).

A konvergenciára, illetve divergenciára vonatkozó állításokat a nem nyugateurópai országok esetében nehezebb megfogalmazni, hiszen ezen országok nagy része 1989-et követően lett önálló állam, így a várható élettartamra vonatkozó adatszolgáltatás is ekkor elkezdődött, illetve legfeljebb 1985-re nyúlik vissza. Hasonló probléma, hogy az adatszolgáltatás jó néhány ország esetében jelentős késésben van, illetve szünetel: Tádzsikisztánra és Üzbegisztánra nézve például 2005. évre érhetők el a legfrissebb adatok (1. táblázat). A terjedelemre vonatkozó becslések tehát szinte minden évben az országok eltérő körére vonatkozhatnak csak.

Mindezen korlátok mellett úgy tűnik, hogy ezen országok között a (trendelemzés által modellált) férfi várható élettartamot tekintve az olló a 2000-es évek első felében nyílt a legnagyobbra. Az 1980-as évek során a legmagasabb és a legalacsonyabb élettartam közötti különbség 9-10 év volt, az 1990-es évek második felében 12-13 év, 2006-ban pedig - maximumát elérve - 14,5 év. Innentől kezdve ez a különbség határozottan csökkent, 2010-ben már 13,2 éven állt, amely egy konvergáló időszak kezdetét jelezheti. 
Ha nem is olyan olyan különbözően, mint ahogyan a férfiak esetében láthattuk, a halálozási minták a nőkre vonatkozóan is másképpen alakultak a nyugateurópai és a nem nyugat-európai országokban. A nyugat-európai országokban a nők születéskor várható élettartamának alakulása lényeges pontokon eltér a férfiakétól. 1970-ben az EU-15-ös országok átlagában 74,8 év volt a női születéskor várható élettartam, amely a 2010-es évek végére 84,07 évre emelkedett. És bár a fejlődés a periódus során mindvégig töretlen volt, az utolsó években ez a trend megtörni látszik, és úgy tünik, mintha egy stagnációs időszak vette volna kezdetét. Az időszak kezdetén a nyugat-európai országokban a legalacsonyabb érték 1971-ben 71,65 év volt (Portugáliában), a legmagasabb pedig 77,6 év (Svédországban). Ez a közel 6 évnyi különbség 2011-re 4 év körülire csökkent: a várható élettartam a 81,87 év (Dániában), és 85,89 év (Franciaországban) között szóródott. Érdekes módon a női EU-15 átlagához a legközelebb a finnországi értékek állnak: a férfiak esetében igen hasonló Franciaország és az Egyesült Királyság a női várható élettartamot tekintve igen különböző pályát járt be (6. ábra).

6. ábra: A nök születéskor várható élettartamának alakulása néhány nyugat-európai országban (a trendelemzés segitségével modellezett értékek)

Evolution of female life expectancy at birth in some Western European countries (modelled values based on trend analysis)

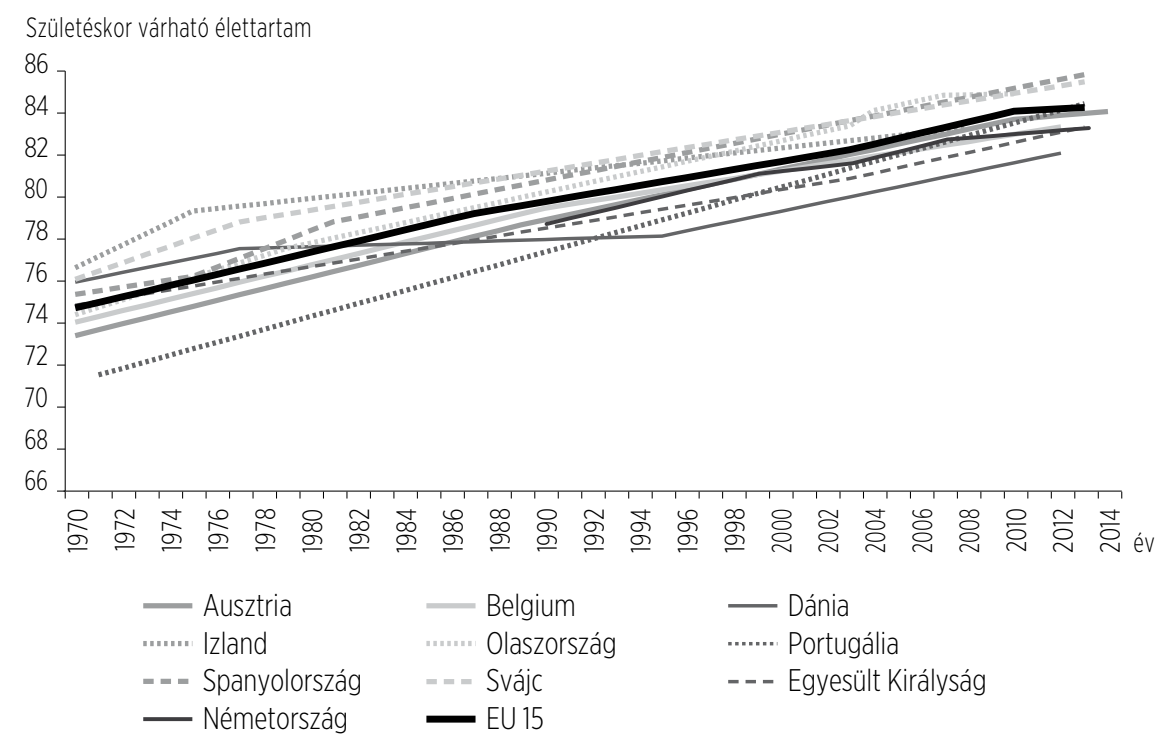

Forrás: European Health for All Database (HFA-DB) adatai alapján a szerző számításai. 
7. ábra: A nők születéskor várható élettartamának alakulása néhány kelet-közép-európai és balti országban (a trendelemzés segitségével modellezett értékek)

Evolution of female life expectancy at birth in some East Central European and Baltic countries (modelled values based on trend analysis)

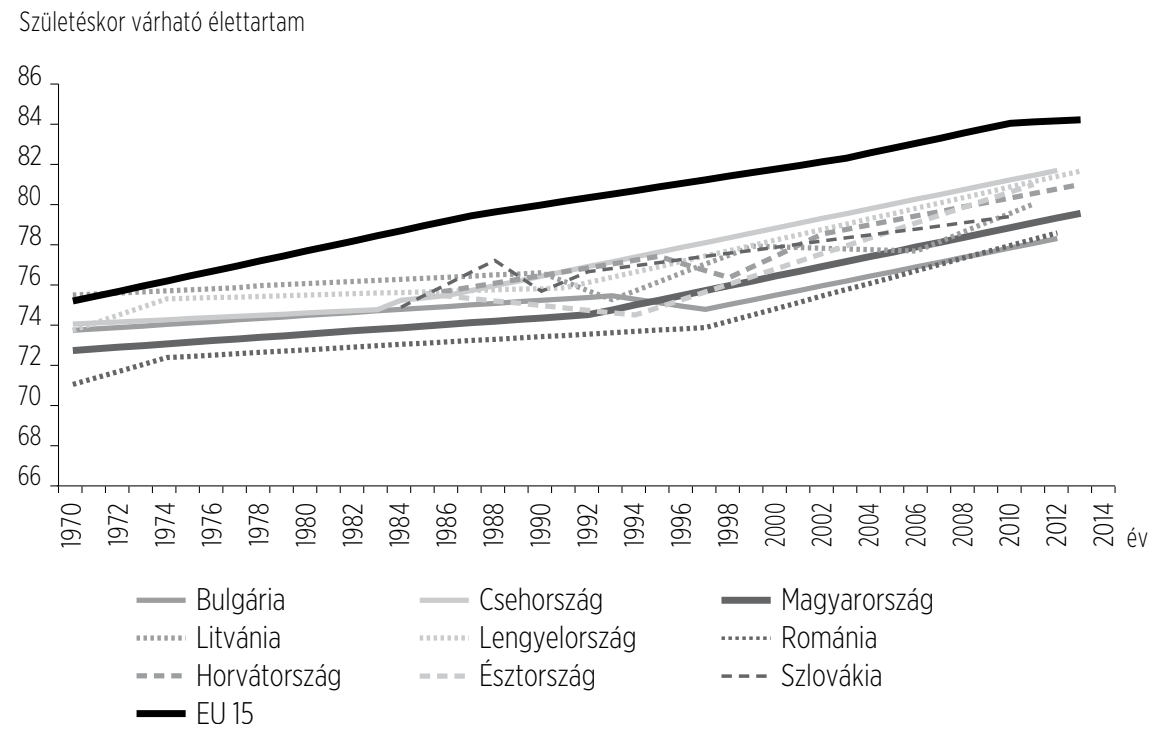

Forrás: European Health for All Database (HFA-DB) adatai alapján a szerző számításai.

Az időszakot általában jellemző konvergencia egyrészt a korábban lemaradt országok felzárkózásából, másrészt a korábban kimagasló várható élettartamú országokban a lassú fejlődés okán az átlag köré „süllyedéséből” következik. Ugyanakkor a nők körében a relatív pozíciók jó néhány ország esetében nagyot változtak. Elsősorban Görögország és Dánia esetében látható jelentős relatív zuhanás: ezek a korábban jóval az EU-15 átlaga feletti teljesítő országok 2011-ben már jelentősen lemaradtak az átlagtól. Svédország, Izland, Norvégia és Hollandia esetében pedig a korábbi viszonylag magas várható élettartamok lassabban növekedtek az átlagos ütemnél, így a 2010-es évek elején az átlag köré sorolódtak az értékek. A periódus elején kissé rosszabbul teljesítő országok (Izrael, Ausztria és Luxemburg), illetve a korábban a legrosszabb pozícióban lévő Portugália és Málta viszont beérték az átlagot. Kevésbé markáns, de felzárkózó tendenciákat lehet látni Belgium és Írország esetében is, míg nagyon enyhe leszakadást az Egyesült Királyság adataiban. Ugyanakkor a női élettartamok körében is megfigyelhető egy „elit klub” jelenléte: az átlagnál mindvégig magasabb az érték Svájcban és Franciaországban. Ezekhez az országokhoz csatlakozott az 1980-as évek során Olaszország, majd az 1990-es években Spanyolország. 
A gyors vagy lassú növekedés, esetleg a ritka stagnációs időszakok váltakozásából összetevődő nyugat-európai mintától a nők esetében is jelentősen különbözik az elemzésünkbe vont többi ország mintázata. Az 1970-es és az 1980-as évek igen lassú növekedését követően mérsékelt volt a halálozási válság Észtországban, Litvániában, Lettországban, Bulgáriában és Szlovákiában. Ezekben az országokban 1-2 évvel csökkent a nők születéskor várható élettartama az 1990-es évek kezdetén. Ennél is mérsékeltebben érintette a halálozási válság Magyarországot és Lengyelországot, ahol tulajdonképpen a korábbi stagnáció folytatódott a szóban forgó időszakban, Csehországban pedig már az 1980-as évek második felében megkezdődött a születéskor várható élettartam emelkedése a nők körében. Ezek után szolid, de látható fejlődés kezdődött minden országban, amelynek üteme Lettországban és Észtországban megközelíti a legdinamikusabbakat, Litvániában azonban visszaesési periódusokkal terhelt (7. ábra).

8. ábra: A nök születéskor várható élettartamának alakulása néhány kelet-európai és közép-ázsiai országban (a trendelemzés segitségével modellezett értékek)

Evolution of female life expectancy at birth in some Eastern European and Central Asian countries (modelled values based on trend analysis)

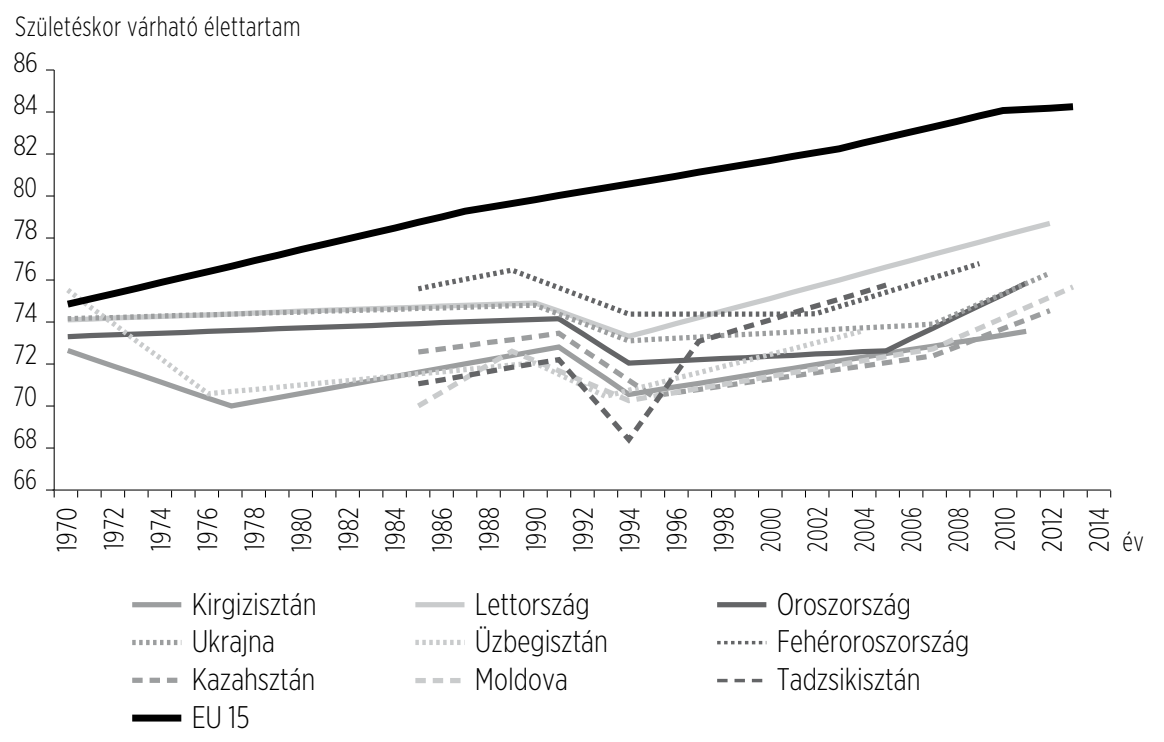

Forrás: European Health for All Database (HFA-DB) adatai alapján a szerző számításai.

A volt szovjet tagköztársaságok döntő többsége viszont a nők várható élettartamának alakulását tekintve is mély halálozási válságot élt meg az 1990-es évek 
kezdetén. Az 1970-es és az 1980-as évek során ezekben az országokban a női várható élettartam csak igen lassan, alig észrevehetően növekedett, majd a halálozási válság kiteljesedésével az élettartamok 3-6 évet zuhantak. Ez a válság elhúzódott Oroszországban, Fehéroroszországban és Ukrajnában, ugyanakkor ezekben az országokban a legutóbbi évek során a női várható élettartam különösen dinamikus növekedésbe kezdett (8. ábra). Más volt tagköztársaságban (Kirgizisztán, Üzbegisztán, Tádzsikisztán és Kazahsztán) a várható élettartam növekedése közvetlenül a válság után elkezdődött, bár a növekedés dinamizmusa kismértékben elmaradt az előbb említett volt tagköztársaságokban tapasztaltak mögött.

Nem tapasztalható a női várható élettartam emelkedése Örményországban és Azerbajdzsánban (9. ábra), amelyeket e tekintetben a leghátrányosabb helyzetű országoknak kell tekintenünk az egész régióban. Nem tudtuk a típusok között elhelyezni a montenegrói és a grúz mintázatokat, valamint a szerbiai és macedóniai idősorok is túl rövidnek bizonyultak az elemzéshez. A régióból egyértelműen Szlovénia válik ki, amely a női várható élettartam tekintetében lényegében már csatlakozott a nyugat-európai országokhoz.

9. ábra: Születéskor várható női élettartamok atipikus alakulása néhány európai országban (a trendelemzés segitségével modellezett értékek)

Atypical evolution of female life expectancy at birth in some European countries (modelled values based on trend analysis)

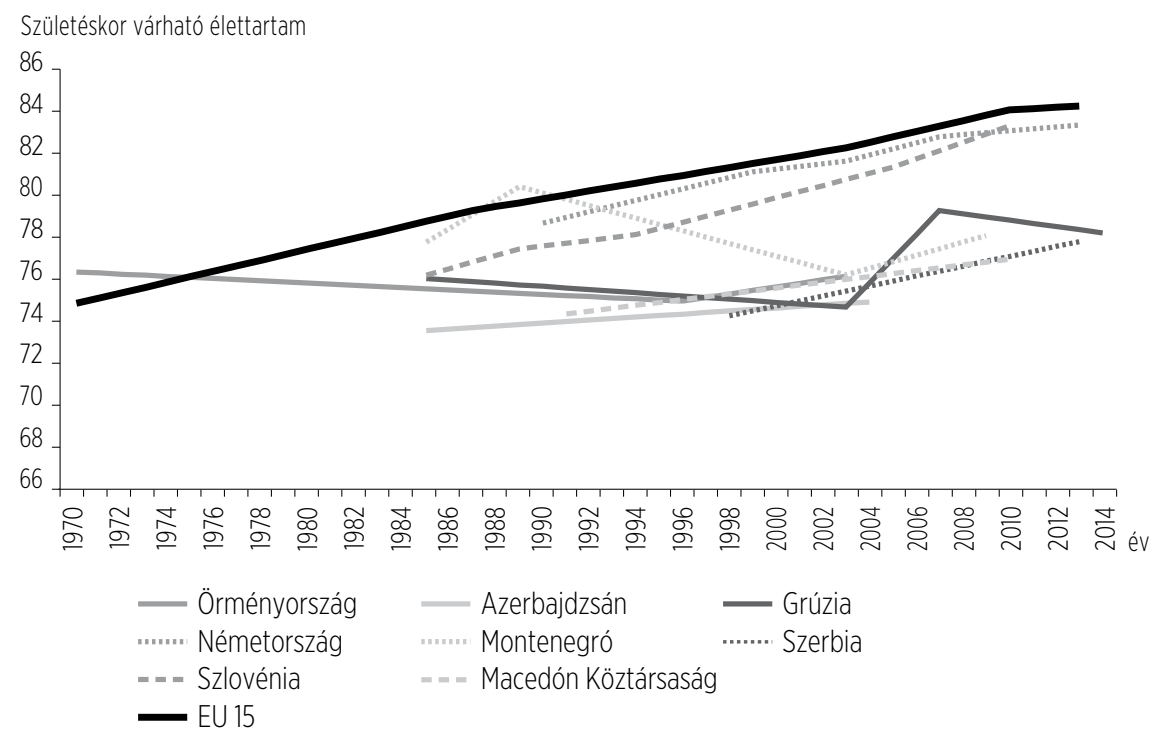

Forrás: European Health for All Database (HFA-DB) adatai alapján a szerző számításai. 


\section{KÖVETKEZTETÉSEK}

Elemzésünkben a WHO Európai Régiójához tartozó országok lehető legtágabb körét próbáltuk meg bevonni abból a célból, hogy a kevesebb adatot közlő országok mortalitási tapasztalatai is megjelenjenek, és tágabb legyen azon bemutatható pályáknak a köre, amelyet a születéskor várható élettartam a vizsgált bő négy évtized során bejárhatott. Ezt a célkitüzést természetesen nem tudtuk teljes körüen megvalósítani, minthogy választott módszerünk, a trendelemzés szükségképpen csak azokra az országokra volt alkalmazható, amelyek viszonylag hosszú időn át komolyabb megszakitás nélkül szolgáltattak férfi és női születéskor várható élettartamra vonatkozó adatokat.

Érdeklődésünk középpontjában a kelet-közép-európai országok, ezen belül Magyarország helyzetének alakulása állt. Ugyanakkor a nyugat-európai országok tapasztalatai is számos tanulsággal szolgáltak. Érdemes felfigyelni arra a jelenségre, hogy a várható élettartamok általános konvergenciája esetén is lehetnek olyan országok, amelyekben a várható élettartam jóval lassabban fejlődik, és saját régiójának éllovasaiból annak sereghajtóivá válnak. A férfi várható élettartamok elemzése ebben a régióban azt mutatta, hogy bár egyenként igen kevés országban tapasztalhatjuk a várható élettartamok növekedésének megszakadását, az EU-15 átlagát tekintve ez a tendencia határozottan megjelent: a 2010-es évek első éveiben mind a férfiak, mind pedig a nők születéskor várható élettartama csak a stagnáláshoz közeli mértékben növekedett. Ugyanakkor meglehetősen bizonytalan, hogy ez az igen rövid, 3 éves periódus kezelhető-e egyáltalán különálló szakaszként az EU-15-ös országcsoport várható élettartamainak fejlődéstörténetében. Ezért a fejlődési ütemek összehasonlitása során az EU-15 1999 és 2010 közötti fejlődési ütemét vettük figyelembe, amely a férfiak esetében évente 0,31 év volt.

A szűkebb régiókhoz - Csehországhoz, Szlovákiához, Lengyelországhoz, Bulgáriához, Szlovéniához, Horvátországhoz, illetve Romániához - képest a magyarországi férfi várható élettartam fejlődése átlagosnak tekinthető annak figyelembevételével, hogy Szlovákia a korábbi időszakokban jelentős, a jelenleginél dinamikusabb növekedési periódusokon esett át.

A 2. táblázatban összefoglalt eredmények alapján látható, hogy a jelenlegi férfi várható élettartamot nagymértékben a „,halálozási krízis időszak” tapasztalatai határozzák meg, kevésbé az utolsó évtized fejleményei. Az 1970-ben még teljesen azonos magyar és lengyel férfi várható élettartam például két évtizede igen hasonló ütemben növekszik, ugyanakkor az ezt megelőző időszakban Magyarországot a hosszú időn keresztül tartó romlás és egy kisebb halálozási válság 
időszakához kötődő visszaesés jellemezte, míg Lengyelországban egyáltalán nem csökkent a várható élettartam a válságidőszakban. A cseh férfiak jelenlegi pozíciójának kialakulásában azonban volt némi szerepe a válság utáni fejlődés dinamikája erősségének.

2. táblázat: A férfiak születéskor várható élettartamának alakulásának néhány jellemzője Magyarországon és néhány környező országban

some indicators of the evolution of male life expectancy in Hungary and some neighbouring countries

\begin{tabular}{lccc} 
Ország & $\begin{array}{c}\text { Az élettartam jelenleg } \\
\text { jellemző ütemű } \\
\text { növekedésének kezdete }\end{array}$ & $\begin{array}{c}\text { Az élettartam jelenlegi } \\
\text { éves növekedésének } \\
\text { üteme }\end{array}$ & $\begin{array}{c}\text { Az EU-15 átlagos } \\
\text { élettartamától való } \\
\text { lemaradás 2012 }\end{array}$ \\
\hline Bulgária & 1996 & 0,22 & 8,2 \\
Csehország & 1999 & $0,29^{a}$ & 3,6 \\
Horvátország & 1992 & 0,33 & 4,9 \\
Lengyelország & 1992 & 0,29 & 6,2 \\
Magyarország & 1993 & 0,35 & 7,5 \\
Szlovákia & 1994 & 0,19 & 6,8 \\
Szlovénia & 1998 & 0,54 & $2,4^{b}$ \\
Románia & 1996 & 0,34 & 7,6 \\
Ukrajna & 2008 & 0,92 & 12,3 \\
\hline
\end{tabular}

Forrás: WHO/Europe 2016 adatai alapján saját számítás.

Megjegyzés: a Ezt a periódust egy gyorsabb fejlődési időszak előzte meg;

${ }^{\mathrm{b}} 2010$.

A régiós országok fejlődésének viszonylagos hasonlósága ugyanakkor más perspektívában is interpretálható. Amennyiben az EU-15 országcsoportra a férfi várható élettartamok fejlődése a korábbiakban hosszú időszakot jellemző szintre (0,31 év várható élettartam növekedés évente) tér vissza, akkor a régiónkba tartozó országoknak - Szlovénia kivételével - nincs esélye arra, hogy a közeli jövőben megközelítsék az EU-15 átlagos férfi várható élettartamát, hiszen a fejlődés üteme nagyon közel esik az EU-15 fejlődési üteméhez.

Magyarországon, illetve a környező országokban a nők születéskor várható élettartamának növekedési ütemét tekintve is meglehetősen kicsik az országok közötti különbségek (3. táblázat). A jelenlegi fejlődési ütem lényegében csak a volt szovjet tagköztársaságok többségében különösen magas. A szűkebb régiónkban fekvő országokban a várható élettartamban mutatkozó jelenlegi különbségek a nők esetében is nagymértékben tulajdoníthatóak a „krízis”-évek tapasztalatainak, illetve az 1989 előtti fejlődés jellegzetességeinek, jóval inkább, mint a későbbi időszakokat jellemző hosszabb távon tapasztalható fejlődési ütemben mutatkozó eltéréseinek. 
Magyarország és Lengyelország helyzetét véve például, az 1970-ben még csak egy évnyi különbség 1970 és 1973 között növekedett a leginkább: a ma is tapasztalható 2-3 éves különbség a női várható élettartamokban már 1974-re kialakult.

3. táblázat: A nök születéskor várható élettartamának alakulásának néhány jellemzője Magyarországon és néhány környező országban

Some indicators of the evolution of female life expectancy in Hungary and some neighbouring countries

\begin{tabular}{lccc}
\hline Ország & $\begin{array}{c}\text { Az élettartam jelenleg } \\
\text { jellemzö ütemü } \\
\text { növekedésének kezdete }\end{array}$ & $\begin{array}{c}\text { Az élettartam jelenlegi } \\
\text { éves növekedésének } \\
\text { üteme }\end{array}$ & $\begin{array}{c}\text { Az EU-15 átlagos } \\
\text { élettartamától való } \\
\text { lemaradás, 2012 }\end{array}$ \\
\hline Bulgária & 1995 & 0,22 & 6,4 \\
Csehország & $1998^{\mathrm{a}}$ & 0,29 & 2,9 \\
Horvátország & $2002^{\mathrm{a}}$ & 0,23 & 2,8 \\
Lengyelország & 1991 & 0,29 & 3,2 \\
Magyarország & 1992 & 0,35 & 5,4 \\
Szlovákia & - - $^{\mathrm{b}}$ & 0,15 & $5,3^{\mathrm{d}}$ \\
Szlovénia & $2005^{\mathrm{c}}$ & 0,40 & $1,2^{\mathrm{d}}$ \\
Románia & 1996 & 0,32 & 6,1 \\
Ukrajna & 2008 & 0,48 & 7,9
\end{tabular}

Forrás: WHO/Europe 2016 adatai alapján saját számítás.

Megjegyzés: ªzt a periódust egy gyorsabb fejlődési periódus előzte meg;

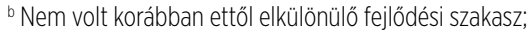

' Ezt a periódust egy lassabb fejlődési periódus előzte meg;

d 2010.

Az Európai Unióval való összehasonlításban most is az EU-15-ös átlag alakulását vesszük alapul. Több nyugat-európai ország esetében is megfigyelhető a női várható élettartamok növekedésének megszakadása, és ez a tendencia tükröződik az EU-15 átlagában is - a stagnálás közeli tendencia kicsit határozottabban jelenik meg a nők körében a 2010-es évek fordulóján a férfiakhoz viszonyítva. Amennyiben ez a tendencia valós és tartósnak bizonyul, akkor természetesen van arra esély, hogy régiónk országai beérjék a többi uniós ország értékeit. A jelenleg érvényes fejlődési ütem mellett ez a felzárkózás a stagnáló európai szinthez is 10 évet igényelne Csehország, 15 évet Magyarország, valamint 30 évet Bulgária esetében. Ugyanakkor, ha a női várható élettartam fejlődése az EU-15 országaiban a 2000-es éveket jellemző átlagos fejlődési ütemhez tér viszsza (0,26 újabb életév-nyereség évente), akkor a felzárkózásra rövidtávon nincs esély, hiszen ez az ütem - a nők esetében is - lényegében megegyezik a régiós országok fejlődési ütemével -, kivéve Szlovéniát, ahol a várható élettartam már felzárkózottnak tekinthető. 
Az elemzés legváratlanabb eredménye annak demonstrációja, hogy a korábban a tág értelemben vett kelet-európai térségben tapasztalható növekvő divergenciáért felelőssé tett országok jó részében az életkilátások a 2010-es év környékén kezdődő nagyon dinamikus növekedési évei kezelhetők önálló szakaszként. Ezek a kimagasló növekedési ütemek (melyeket a 2. és 3. táblázatban Ukrajna szemléltet) azt sugallják, hogy amennyiben a növekedési ütem nem törik meg, Oroszország, Ukrajna, illetve Fehéroroszország néhány éven belül elérheti a közép-európai országokat mind a férfi, mind pedig a női életkilátásokat illetően. Ez a szcenárió ugyanakkor nem valószínűsíthető a múlt tükrében, hiszen ezekben az országokban több alkalommal előfordultak már ilyen dinamikájú, gyors változások mind pozitív, mind negatív irányban.

A közelmúltra vonatkozóan tehát, néhány közép-ázsiai ország változatlanul kedvezőtlen halálozási viszonyaira való figyelem mellett bizton állítható, hogy a legnagyobb népességű kelet-európai országokban megindult kedvező változásoknak köszönhetően a tág értelemben vett kelet-európai régióban - 2008 és 2012 között - az életkilátások konvergálni kezdtek egymás felé.

A kelet-európai országok általános konvergencia jelenségei mellett tanulmányunk másik alapkérdése az volt, hogy érdemes-e az élettartamok alakulását a klubszemlélet keretein belül elemezni. A válasz különbözik a férfi, illetve a női születéskor várható élettartamokra vonatkozóan.

A nők esetében a korábbi elemzésekben világosan elkülönült egymástól a nyugat-európai, a közép-kelet-európai, illetve a kelet-európai országok csoportja. Ugyanakkor ezek a csoportok nem teljesítik azokat a feltételeket, amelyeket a „klubok”-tól várnánk: az egyes csoportok belső heterogenitása jelentős a csoportok határai közötti távolságokhoz viszonyítva.

A férfi élettartamok alakulására vonatkozó eredmények azonban nem erősítik meg azt a feltételezést, amelyek szerint egységes közép-európai minta létezne, és különféle klubok körvonalai is felsejlenek.

A részletes elemzésben bemutatott, tágabb csoportosítást követően egy szűkebb csoportosítást is elkészítettünk a hozzáférhető hosszabb idősorok figyelembevételével a férfi várható élettartamok alakulására vonatkozóan. A rövid, illetve nem konzisztens idősorok (amelyek elsősorban a középázsiai országokra vonatkoztak) kihagyásával a következő csoportosítás jött létre: 
4. táblázat: Európai országok lehetséges klubjai a férfi születéskor várható élettartam alakulása alapján

Likely clubs of countries by the evolution of male life expectancy at birth

$\begin{array}{ll}\text { Nyugat-Európa } & \text { Ausztria, Belgium, Dánia, Finnország, Franciaország, Görögország, Izland, } \\ & \text { Írország, Olaszország, Luxemburg, Hollandia, Norvégia, Portugália, } \\ & \text { Spanyolország, Svédország, Svájc, Egyesült Királyság, Németország } \\ \text { Közép-Kelet-Európa_A } & \text { Csehország, Lengyelország, Horvátország } \\ \text { Közép-Kelet-Európa_B } & \text { Bulgária, Magyarország, Románia, Szlovákia } \\ \text { Balti államok } & \text { Lettország Litvánia, Észtország } \\ \text { Kelet-Európa } & \text { Oroszország, Fehéroroszország, Ukrajna }\end{array}$

A történeti mintázatok alapján több jellegzetes csoportot is el lehet különíteni. Ezek közül a nyugat-európai, a közép-kelet-európai („B”-vel jelölt) és a kelet-európai országok csoportjait kiemelve olyan három, jellegzetesen elküIönülő csoporthoz jutunk, amelyek egymáshoz képest egyre inkább elkülönült klubként látszódnak. A kelet-közép-európai klaszter belső inhomogenitása például 1995-től kezdve kisebb, mint a nyugat-európai klaszter alsó határától való távolsága. A kelet-európai klasztertől való távolsága pedig 1998-tól kezdve nagyobb, mint belső differenciáltsága. A közép-kelet-európai klaszter, illetve ezzel együtt a három klub rendszere tehát az 1990-es évek végétől kiformálódottnak tekinthető.

Mindezek mellett azonban a történeti mintázatok alakulása szerint további két országcsoport is elkülönült: a „közép-kelet-európai A” és a balti országcsoport. Ezek az országcsoportok azonban semmiképpen nem tekinthetők elkülönülő „kluboknak”. Lengyelország és Csehország esetében nagy az esélye, hogy éppen annak a folyamatnak vagyunk a tanúi, amelynek során ezek az országok elhagyják a kelet-európai klasztert, és csatlakoznak a nyugateurópaihoz. A balti országok esetében pedig akár különböző szcenáriók megvalósulását is valószínűsíthetjük az egyes országokban: egyesekre nézve a nyugat-európai, másokra nézve a kelet-európai klaszterhez való csatlakozás tűnik valószínübbnek (10. ábra). 
10. ábra: A férfi várható élettartam szerinti lehetséges klubok Európában

Evolution of likely clubs of countries by male life expectancy

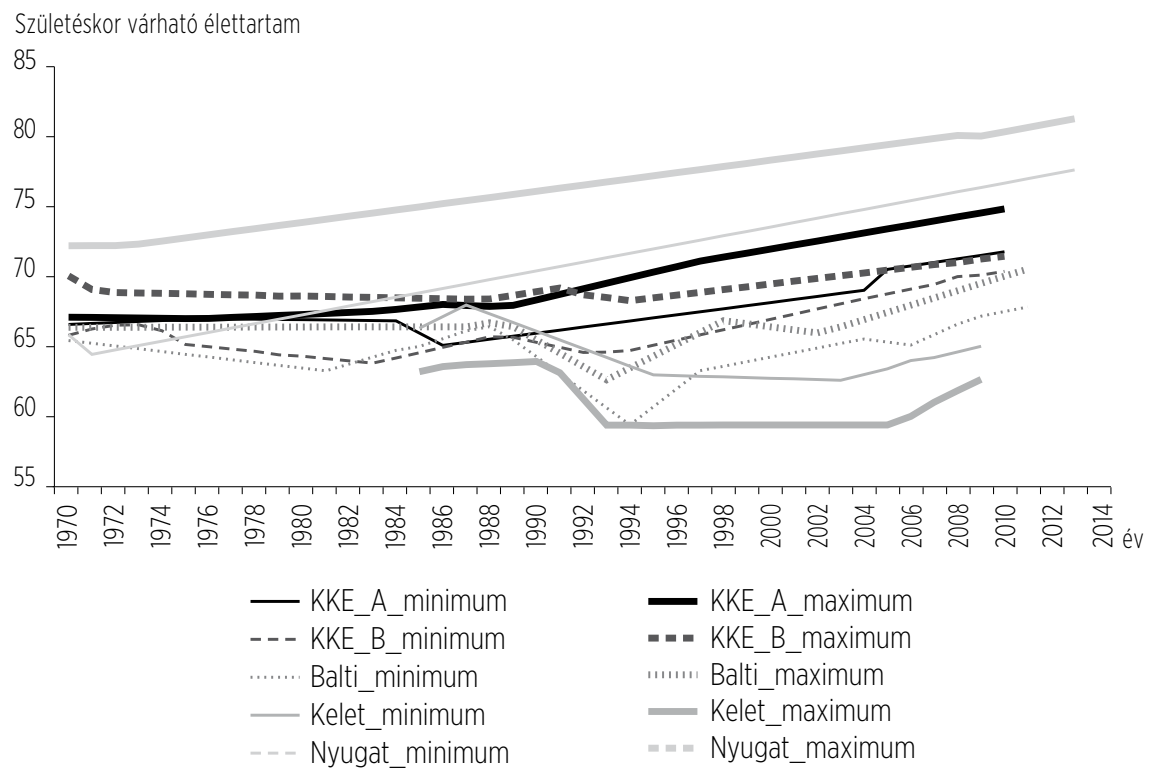

Forrás: European Health for All Database (HFA-DB) adatai alapján a szerző számitásai.

Elemzésünk összességében csak kevésbé módosította a születéskor várható élettartamok európai fejlődéséről kialakult korábbi képet. Magyarország vonatkozásában azonban eredményeink szerint elképzelhető, hogy a jövőben a férfiak várható élettartamának alakulását nem a visegrádi országokkal, hanem Romániával és Bulgáriával összehasonlítva kell majd elemeznünk. 
MELLÉKLETEK

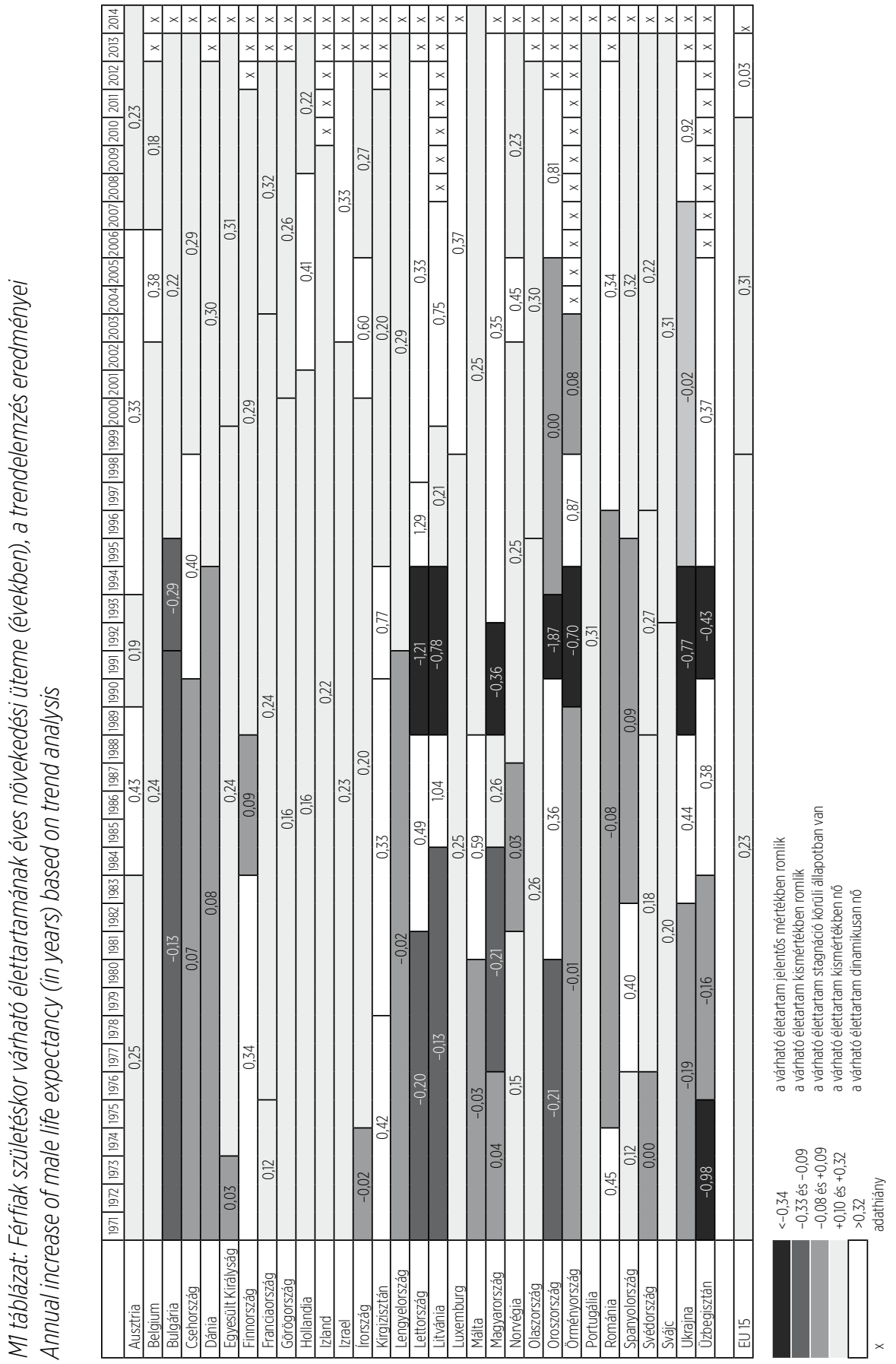




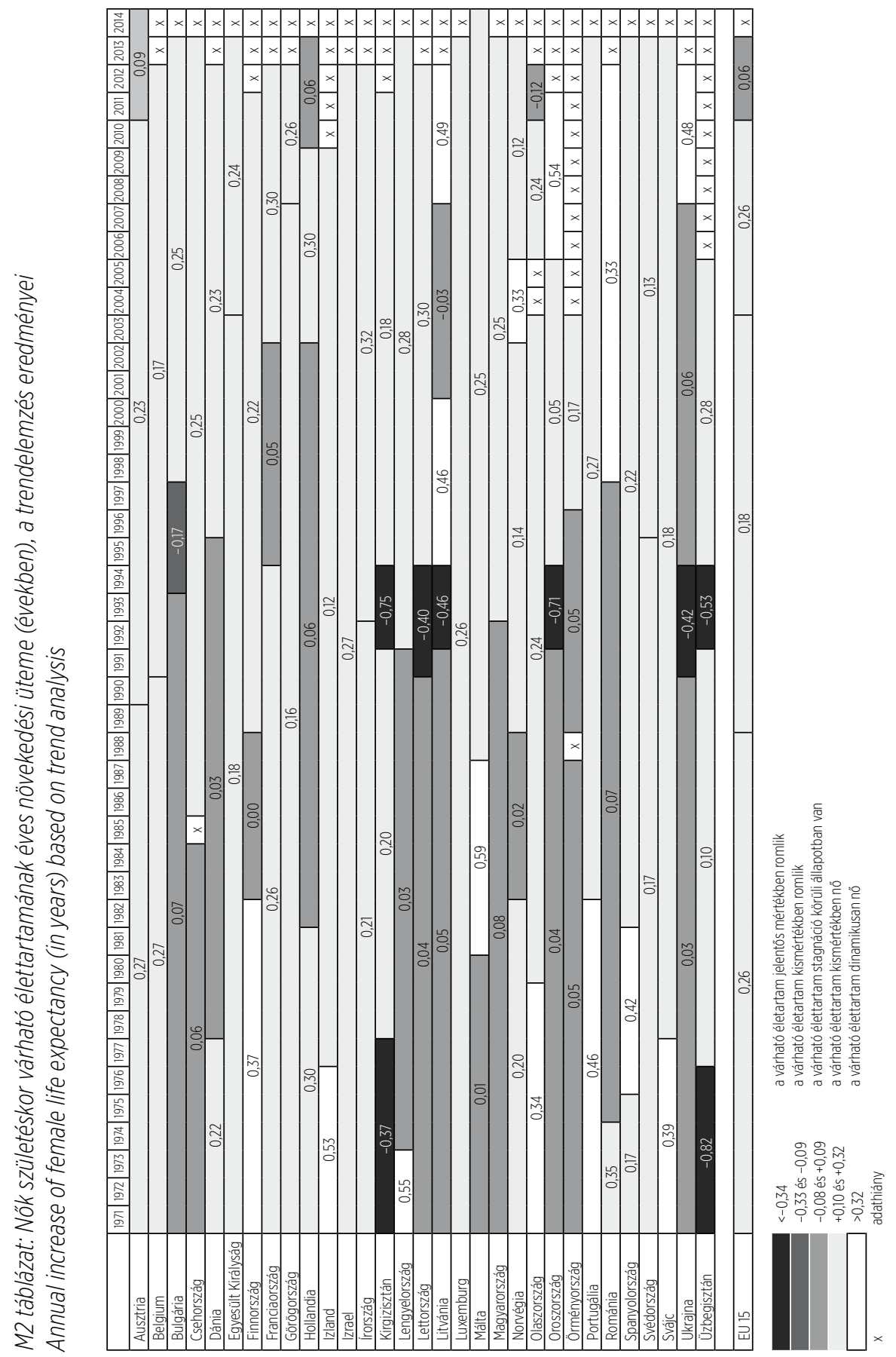




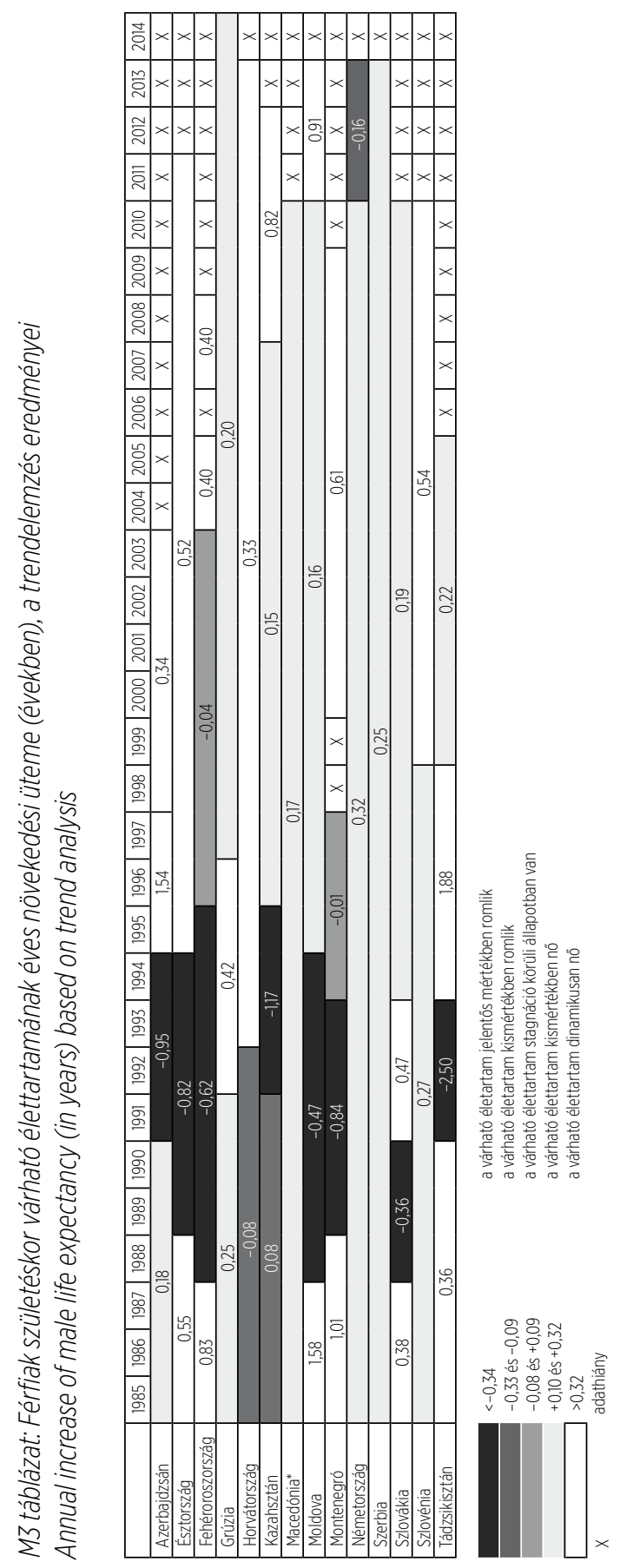




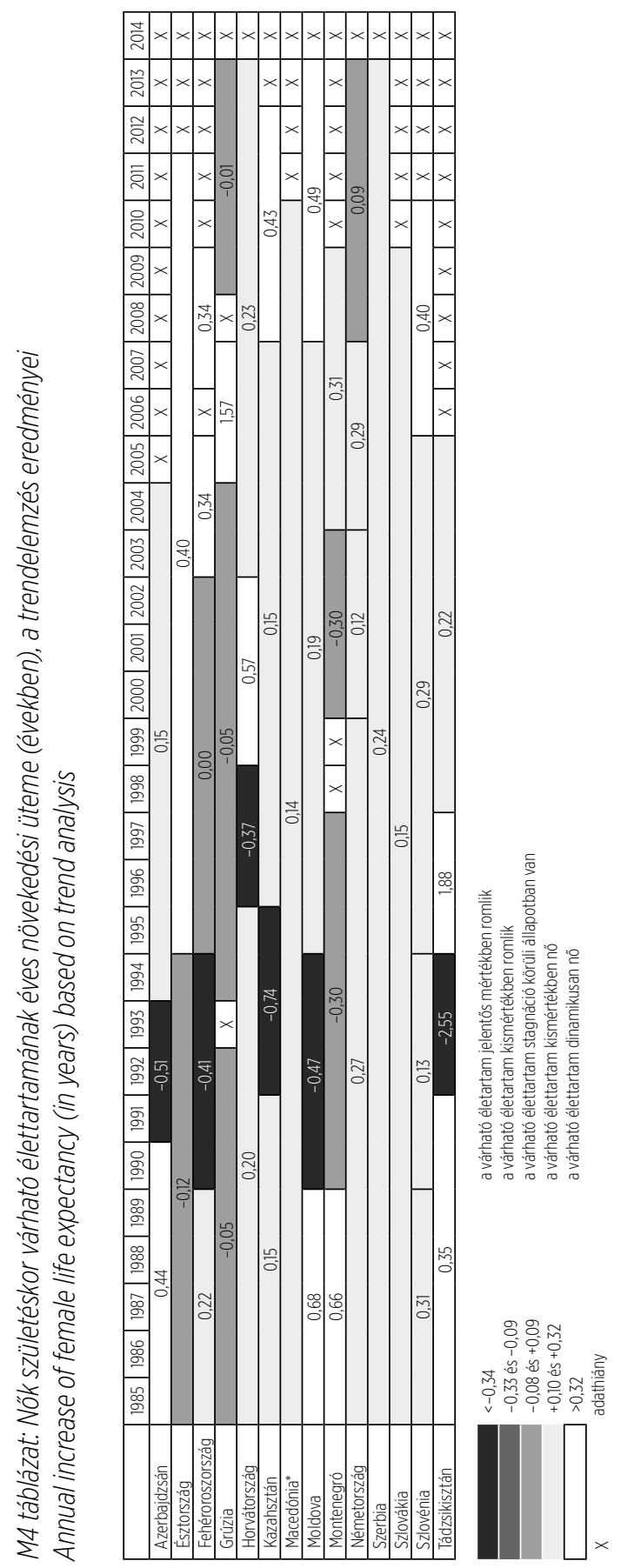




\section{IRODALOM}

Arriaga, Eduardo - Kingsley, Davis K. 1969: The Pattern of Mortality Change in Latin America. Demography, 6(3), 223-242.

Bloom, David E - Canning, David 2007: Mortality traps and the dynamics of health transitions. Proceedings of the National Academy of Sciences of the United States of America, 104(41), 16044-16049.

Canning, David 2012: Progress in Health around the World. The Journal of Development Studies, 48(12), 1784-1798.

Casabonne, Ursula - Kenny, Charles 2012: The Best Things in Life are (Nearly) Free: Technology, Knowledge, and Global Health. World Development, 40(1), 21-35.

d'Albis, Hippolyte - Esso, Loesse Jacques - Pifarré i Arolas, Hector 2014: Persistent Differences in Mortality Patterns across Industrialized Countries, PLOS ONE, 9(9), e106176. doi:10.1371/journal.pone.0106176

Edwards, Ryan D. 2010: Trends in World Inequality in Life Span since 1970. NBER Working Paper No. 16088. http://www.nber.org/papers/w16088, National Bureau of Economic Research, 1050 Massachusetts Avenue, Cambridge, MA 02138.

Edwards, Ryan D. 2011: Changes in World Inequality in Length of Life: 1970-2000. Population and Development Review, 37(3), 499-528.

Edwards, Ryan D. - Tuljapurkar, Shripad 2005: Inequality in life spans and a new perspective on mortality convergence across industrialized countries. Population and Development Review, 31(4), 645-674.

Gillespie, Duncan O. S. - Trotter, Meredith V. - Tuljapurkar, Shripad D. 2014: Divergence in age patterns of mortality change drives international divergence in lifespan inequality. Demography, 51(3), 1003-1017.

Glei, Dana A. - Meslé, France - Vallin, Jacques 2010: Diverging Trends in Life Expectancy at Age 50: Look at Causes of Death. In Crimmins, Eileen M. - Preston, Samuel H. Cohen, Barney (eds.): International differences in mortality at older ages: Dimensions and sources. The National Academies Press, Washington, DC, 17-67.

Goesling, Brian - Firebaugh, Glenn 2004: The Trend in International Health Inequality. Population and Development Review, 30(1), 131-146.

Goli, Srinivas - Arokiasamyb, Perianayagam 2014: Maternal and child mortality indicators across 187 countries of the world: Converging or diverging. Global Public Health, 9(3), 342-360.

Helis, Eftihia - Augustincic, Lana - Steiner, Sabine - Chen, Li - Turton Penelope - Fodor, George J. 2010: Time trends in cardiovascular and all-cause mortality in the 'old' and 'new' European Union countries. European Journal of Cardiovascular Prevention \& Rehabilitation, 18(3), 347-359.

Hum, Ryan J. - Jha, Prabhat - McGahan, Anita M. - Cheng, Yu-Ling 2012: Global divergence in critical income for adult and childhood survival: analyses of mortality using Michaelis-Menten. eLife 2012, 1:e00051. DOI: 10.7554/eLife.00051

Joinpoint Trend Analysis Software, Version 3.5. 1, http://surveillance.cancer.gov/joinpoint/ 
Kim, Hyune-Ju - Fay, Michael P. - Feuer, Eric J. - Midthune, Douglas N. 2000: Permutation tests for joinpoint regression with applications to cancer rates. Statistics in Medicine, 19(3), 335-51. (correction: 2001;20:655).

Lehmijoki, Ulla 2009: Global Trends in Life Expectancy: A Club Approach. Finnish Yearbook of Population Research, 33-47.

Luy, Marc - Wegner, Christian - Lutz, Wolfgang 2011: Adult morality in Europe. In Rogers, Richard G. - Crimmins, Eileen M. (eds): International Handbook of Adult Mortality. Springer Science+Business Media B. V., Dordrecht, 49-81.

Mackenbach, Johan P. 2013: Convergence and divergence of life expectancy in Europe: a centennial view. European Journal of Epidemiology, 28(3), 229-240.

Mayer-Foulkes, David 2001: Convergence clubs in cross-country life expectancy dynamics. WIDER World Institute for Development Economics Discussion Paper, No. 2001/134, ISBN 9291900915.

Mayer-Foulkes, David 2005: Human Development Traps and Economic Growth, In López-Casasnovas, Berta Rivera - Currais, Luis (eds.): Health and Economic Growth: Findings and Policy Implications. MIT Press, Cambridge, MA, 115-142.

McMichael, Anthony J. - Mckee, Martin - Shkolnikov, Vladimir - Valkonen, Tapani 2004: Mortality trends and setbacks: global convergence or divergence? Lancet, 363(9415), 1155-1159.

Meslé, France 2004: Mortality in Central and Eastern Europe. Demographic Research, Special Collection, 2(3), 45-70.

Meslé, France - Vallin, Jacques 2011: Historical trends in mortality. In Rogers, Richard G. - Crimmins, Eileen M. (eds): International Handbook of Adult Mortality. Springer Science+Business Media B. V., Dordrecht, 9-47.

Moser, Kath - Shkolnikov, Vladimir - Leon, David A. 2005: World mortality 1950-2000: divergence replaces convergence from the late 1980s. Bulletin of the World Health Organization, 83(3), 202-209.

Preston, Samuel H. 1975: The Changing Relation between Mortality and Level of Economic Development. Population Studies, 29(2), 231-248.

Raskina, Yulia - Tsyplakova, Daria 2014: Club convergence in health outcomes in OECD countries. http://www.iep.ru/files/news/scientcouncil/2014.06.05/raskina.pdf Letöltés: 2016. január.

Rogers, Richard G. - Crimmins, Eileen M. (eds.) 2011: International Handbook of Adult Mortality. Springer Science+Business Media B. V., Dordrecht.

Safaei, Jalil 2012: Post-Communist Health Transitions in Central and Eastern Europe. Economics Research International, 2012, Article ID 137412, doi:10.1155/2012/137412.

United Nations 2012: Changing Levels and Trends in Mortality: the role of patterns of death by cause. United Nations Department of Economic and Social Affairs, Population Division. United Nations publication, ST/ESA/SER.A/318.

Vallin, Jacques - Meslé, France 2004: Convergences and divergences in mortality: a new approach of health tansition. Demographic Research, Special Collection, 2(2), 11-44.

Vallin, Jacques - Meslé, France 2009: The Segmented Trend Line of Highest Life Expectancies. Population and Development Review, 35(1), 159-187. 
Vollmer, Sebastian - Holzmann, Hajo - Ketterer, Florian - Klasen, Stephan - Canning, David 2013: The Emergence of Three Human Development Clubs. PLOS ONE, 8(3), e57624. doi:10.1371/journal.pone.0057624

WHO/Europe 2016: Wold Health Organization, Regional Office for Europe. European health for all database WHO/Europe July 2016. http://data.euro.who.int/hfadb/

Wilson, Chris 2001: On the Scale of Global Demographic Convergence 1950-2000. Population and Development Review, 27(1), 155-171. 


\section{DO LIFE EXPECTANCIES CONVERGE IN EUROPE?}

\section{ABSTRACT}

Based on the so-called club-approach to the evolution of life expectancy the study investigates the evolution in life expectancies of European males and females from 1971 to the latest year with published data at about 2010-2012. In order to widen the field of the possible scenarios, the dynamics of the life expectancy developments of countries with shorter reporting time have also been considered. Trend analysis has been applied in order to group countries by their patterns of development in life expectancy.

Regarding females, Western, East Central and Eastern European countries have been separated, although these groups cannot be considered separated clubs. For males, however, not only the Western, Eastern, Baltic and the East Central European groups showed distinguished patterns, but from 2008 onwards the members of the East Central one appeared to diverge further as the group of the Czech Republic, Poland and Croatia could be separated from that of Bulgaria, Romania, Hungary and Slovakia. 